\title{
Synthesis of Pentasaccharide Repeating Unit Corresponding to the Cell Wall O-Polysaccharide of Salmonella enterica 055 Strain Containing a Rare Sugar 3-Acetamido-3-deoxy-D-fucose
}

\author{
Arin Gucchait \\ Monalisa Kundu \\ Anup Kumar Misra* \\ Division of Molecular Medicine, Bose Institute, P-1/12, \\ C.I.T. Scheme VII-M, Kolkata-700054, India \\ akmisra69@gmail.com
}

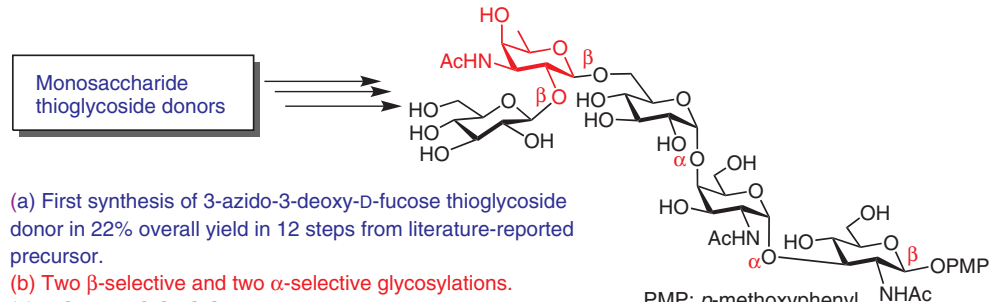

(b) Two $\beta$-selective and two $\alpha$-selective glycosylations.

(c) $\mathrm{NIS}$ and $\mathrm{HClO}_{4}-\mathrm{SiO}_{2}$ as glycosylation activator.

(d) Pentasaccharide from monosaccharide intermediates in $9 \%$

overall yield in 12 steps.
Received: 24.04.2021

Accepted after revision: 31.05.2021

Published online: 24.06 .2021

DOI: 10.1055/s-0037-1610777; Art ID: ss-2021-g0237-op

Abstract A pentasaccharide repeating unit corresponding to the cell wall $O$-antigen of Salmonella enterica 055 containing a rare sugar, 3-acetamido-3-deoxy-D-fucose has been synthesized as its $p$-methoxyphenyl glycoside using a sequential stereoselective glycosylation strategy. A suitably functionalized 3-azido-3-deoxy-D-fucose thioglycoside derivative was prepared in very good yield and used in the stereoselective glycosylation reaction. Functionalized monosaccharide intermediates were prepared judiciously and stereoselectively assembled to get the desired pentasaccharide derivative in excellent yield.

Key words pentasaccharide, glycosylation, 3-acetamido-3-deoxy-Dfucose, Salmonella enterica, stereoselective

Food borne gastrointestinal disorders causing hospitalization and deaths are serious concern all over the world and particularly in the developing countries. ${ }^{1,2}$ Lack of adequate sanitization and intake of contaminated food and water are major cause of diarrheal infections. ${ }^{3,4}$ There are several pathogenic bacteria causing diarrheal outbreaks, which include Escherichia coli (E. coli), ${ }^{5}$ Shigella, ${ }^{6}$ Vibrio cholerae, ${ }^{7}$ Proteus, ${ }^{8}$ and Salmonella ${ }^{9}$ strains. The gastrointestinal disorders caused by the Salmonella infection are termed as salmonellosis, ${ }^{10}$ which are generally being treated with antimicrobial agents. ${ }^{11}$ The causative agent of most of the occurrence of salmonellosis in humans and animals are Salmonella enterica (S. enterica) strains. ${ }^{12}$ Most common symptoms of Salmonella infections are diarrhea, fever, vomiting with dehydration etc. Although a variety of therapeutics are being used for controlling food borne illness or diarrheal infections, they become ineffective because of the emergence of multidrug-resistant bacterial strains. ${ }^{13}$ As a result, there is a strong need to develop alternative approaches for controlling salmonellosis. In general, the polysaccharides present in the cell wall of the virulent bacteria play the pivotal role in their pathogenicity and initial stage of infection to the host. ${ }^{14}$ Among several strains of S. enteri$c a$, responsible for diarrheal infections in humans, S. enterica 055 deserves special attention due to its unique cell wall polysaccharide structure containing a rare sugar, 3-amino3-deoxy-D-fucose moiety. Liu et al. ${ }^{15}$ reported the structure of the pentasaccharide repeating unit of the cell wall polysaccharide of $S$. enterica, which is composed of five monosaccharide moieties namely, $\beta$-D-glucose, $\alpha$-D-glucose, $N$ acetyl- $\alpha$-D-galactosamine, $N$-acetyl- $\beta$-D-glucosamine, and $\beta$-3-acetamido-3-deoxy-D-fucose. In the past, polysaccharide-based glycoconjugates have emerged as effective vaccine candidates against several bacterial infections such as influenza, ${ }^{16}$ pneumococcal, ${ }^{17}$ and meningitis ${ }^{18}$ infections. Despite the possibility of obtaining the polysaccharides from bacterial sources using biofermentation techniques, it suffers from several drawbacks, such as heterogeneity of isolated polysaccharides, handling of live bacterial strains, difficult-to-remove biological impurities etc. In contrast, chemical synthesis of the polysaccharide fragments could provide homogeneous oligosaccharides with confirmed structures. In the recent past, a number of reports appeared from our laboratory towards the synthesis of cell wall oligosaccharides and their glycoconjugates of Salmonella strains. ${ }^{19}$ In continuation, a concise synthesis of the pentasaccharide repeating unit of the cell wall polysaccharide of S. enterica 055 is reported herein. The synthetic strategy involves the synthesis of a rare sugar derivative, i.e. 3-azido3-deoxy- $\beta$-D-fucosyl thioglycoside 5 (Figure 1 ).

In order to synthesize the target pentasaccharide $\mathbf{1}$, a sequential glycosylation strategy has been adopted. The suitably functionalized monosaccharide derivatives $2,{ }^{20} 3,{ }^{21} 4,{ }^{22}$ $\mathbf{5}$, and $\mathbf{6}^{23}$ were prepared following the reaction conditions reported earlier. Thioglycoside derivatives $\mathbf{3}, \mathbf{4}, \mathbf{5}$, and $\mathbf{6}$ were used as glycosyl donors for the elongation of the oligosaccharide chain under a generalized stereoselective glyco- 


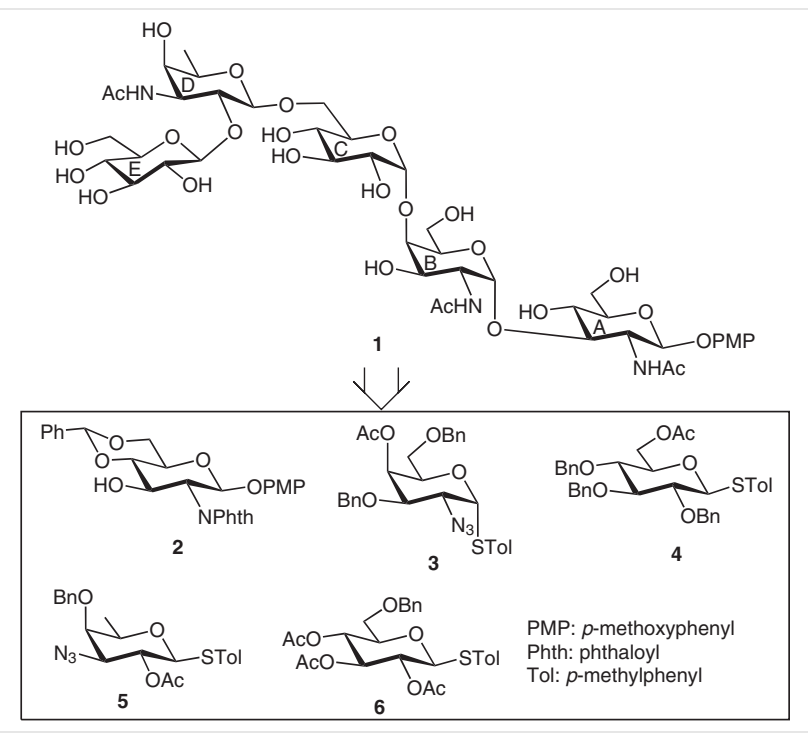

Figure 1 Structure of the synthesized pentasaccharide corresponding to the repeating unit of the cell wall polysaccharide of Salmonella enterica O55 strain

sylation condition in the presence of a combination ${ }^{19 a, 24}$ of $\mathrm{N}$-iodosuccinimide (NIS) and perchloric acid supported over silica $\left(\mathrm{HClO}_{4}-\mathrm{SiO}_{2}\right)^{25}$ as thiophilic glycosylation activator.

Recently, $\mathrm{HClO}_{4}-\mathrm{SiO}_{2}$ has found applications in various types of organic transformations as a cheap, moisture stable, non-corrosive, solid protic acid equivalent. ${ }^{26}$ Most of the conventionally used thiophilic activators ${ }^{27}$ (e.g., triflic acid, TMSOTf, methyl triflate, DMTST) are moisture sensitive and corrosive in nature. Replacement of the corrosive and moisture sensitive acidic reagents by $\mathrm{HClO}_{4}-\mathrm{SiO}_{2}$ resulted satisfactory yields in stereoselective glycosylations. ${ }^{19 \mathrm{a}, 24}$ Due to the simplicity of its preparation and compatibility with the glycosylation reactions and functional groups transformations in carbohydrates, $\mathrm{HClO}_{4}-\mathrm{SiO}_{2}$ in combination with NIS has been used in the present synthetic strategy for the activation of thioglycoside donors.

The rare sugar derivative $\mathbf{5}$, was prepared from the D-fucose thioglycoside derivative using a multistep reaction sequence involving selective protection-deprotection of hydroxyl groups and double $\mathrm{S}_{\mathrm{N}} 2$ inversion reactions. ${ }^{19 a}$

$p$-Methylphenyl 2-O-benzoyl-1-thio- $\beta$-D-fucopyranoside $(\mathbf{7}), 28$ prepared from D-galactose in eight steps was subjected to a number of reactions involving: (a) selective p-methoxybenzylation at the C-3 hydroxyl group via the formation of stannylidene acetal using dibutyltin oxide followed by treatment with $p$-methoxybenzyl chloride $(\mathrm{PMBCl})$ in the presence of tetrabutylammonium bromide (TBAB); ${ }^{29}$ (b) benzylation of the C-4 hydroxyl group using benzyl bromide in the presence of sodium hydride; ${ }^{30}$ and (c) oxidative removal of the PMB group using DDQ in a biphasic reaction condition ${ }^{31}$ to give $p$-methylphenyl
4-O-benzyl-2-O-benzoyl-1-thio- $\beta$-D-fucopyranoside (8) in $72 \%$ overall yield. Compound 8 was treated with triflic anhydride in the presence of pyridine to give the triflyl derivative, which was immediately treated with sodium nitrite ${ }^{32}$ to furnish corresponding D-gulose derivative, which on de$O$-benzoylation using sodium methoxide resulted $p$-methylphenyl 4-O-benzyl-1-thio- $\beta$-D-gulopyranoside (9) in overall $58 \%$ yield. Selective protection of the 2-hydroxy group in compound $\mathbf{9}$ with the 2-naphthylmethyl (NAP) group via the formation of stannylidene acetal by the treatment with dibutyltin oxide followed by treatment of the stannylidene acetal with 2-naphthylmethyl bromide (NAP$\mathrm{Br})$ in the presence of cesium fluoride ${ }^{33}$ furnished $p$-methylphenyl 4-O-benzyl-2-O-(2-naphthylmethyl)-1-thio- $\beta$-Dgulopyranoside (10) in $80 \%$ yield. Compound 10 was subjected to a sequence of functional group transformations which include: (i) treatment with triflic anhydride in the presence of pyridine to give the 3-O-triflyl derivative; (ii) $\mathrm{S}_{\mathrm{N}} 2$ substitution of the 3-O-triflyl group with an azido group by treatment with sodium azide; ${ }^{34}$ (iii) oxidative removal of the NAP group using DDQ in a biphasic reaction condition; ${ }^{35}$ and finally (iv) acetylation of the free hydroxyl group to furnish $p$-methylphenyl 2-O-acetyl-3-azido-4-Obenzyl-3-deoxy-1-thio- $\beta$-D-fucopyranoside (5) in $65 \%$ overall yield (Scheme 1 ). All synthetic intermediates were characterized by their NMR and mass spectral analysis.

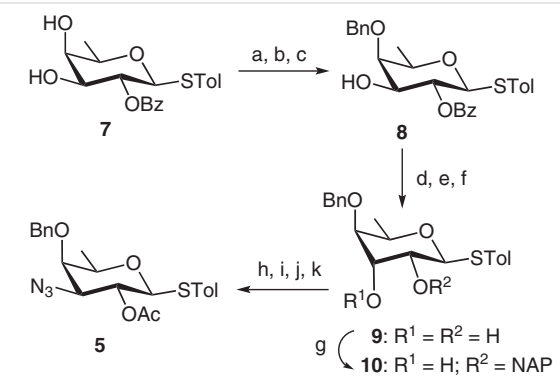

Scheme 1 Reagents and conditions: (a) (i) $\mathrm{Bu}_{2} \mathrm{SnO}, \mathrm{CH}_{3} \mathrm{OH}, 80^{\circ} \mathrm{C}, 3 \mathrm{~h}$; (ii) PMBCl, TBAB, DMF, $65^{\circ} \mathrm{C}, 6$ h; (b) benzyl bromide, NaH, DMF, r.t., 2 h; (c) DDQ, $\mathrm{CH}_{2} \mathrm{Cl}_{2} / \mathrm{H}_{2} \mathrm{O}$ (10:1), r.t., $3 \mathrm{~h}, 72 \%$ (3 steps); (d) $\mathrm{Tf}_{2} \mathrm{O}$, pyridine, $\mathrm{CH}_{2} \mathrm{Cl}_{2},-10{ }^{\circ} \mathrm{C}, 2 \mathrm{~h}$; (e) $\mathrm{NaNO}_{2}$, DMF, $60{ }^{\circ} \mathrm{C}, 12 \mathrm{~h}$; (f) $0.1 \mathrm{M} \mathrm{CH}_{3} \mathrm{ONa}$, $\mathrm{CH}_{3} \mathrm{OH}$, r.t., 3 h, $65 \%$ (3 steps); (g) (i) $\mathrm{Bu}_{2} \mathrm{SnO}, \mathrm{CH}_{3} \mathrm{OH}, 80^{\circ} \mathrm{C}, 3$ h; (ii) 2-(bromomethyl)naphthalene (NAPBr), $\mathrm{CsF}, \mathrm{DMF}, 65^{\circ} \mathrm{C}, 6 \mathrm{~h}, 80 \%$; (h) $\mathrm{Tf}_{2} \mathrm{O}$, pyridine, $\mathrm{CH}_{2} \mathrm{Cl}_{2},-10{ }^{\circ} \mathrm{C}, 2 \mathrm{~h}$; (i) $\mathrm{NaN}_{3}, \mathrm{DMF}, 60^{\circ} \mathrm{C}, 12 \mathrm{~h}$; (j) $\mathrm{DDQ}, \mathrm{CH}_{2} \mathrm{Cl}_{2} / \mathrm{H}_{2} \mathrm{O}(10: 1)$, r.t., 3 h; (k) $\mathrm{Ac}_{2} \mathrm{O}$, pyridine, r.t., $3 \mathrm{~h}, 65 \%$ (4 steps).

Having a set of suitably functionalized thioglycoside donors and acceptors in hand, attempts were made to couple monosaccharide derivatives by stereoselective glycosylations in the presence of a combination ${ }^{19 a, 24}$ of $\mathrm{N}$-iodosuccinimide (NIS) and perchloric acid supported over silica (HC$\left.\mathrm{IO}_{4}-\mathrm{SiO}_{2}\right)^{25}$ as thiophilic activator. Stereoselective glycosylation of compound 2 with 2-azido-2-deoxy-D-galactose thioglycoside derivative $\mathbf{3}$ in the presence of a combination ${ }^{19 a, 24}$ of $\mathrm{NIS}$ and $\mathrm{HClO}_{4}-\mathrm{SiO}_{2}$ furnished disaccharide de- 
rivative 11, which on subsequent de-O-acetylation using sodium methoxide gave disaccharide acceptor 12 in 69\% over all yield. NMR spectroscopic analysis of compound $\mathbf{1 2}$ confirmed it stereoselective formation [signals at $\delta=5.74$ $\left(\mathrm{d}, J=8.5 \mathrm{~Hz}, \mathrm{H}-1_{\mathrm{A}}\right), 5.64(\mathrm{~s}, \mathrm{PhCH}), 5.37$ (d, $\left.J=3.5 \mathrm{~Hz}, \mathrm{H}-1_{\mathrm{B}}\right)$ in ${ }^{1} \mathrm{H}$ NMR and $\delta=101.5(\mathrm{PhCH}), 98.6\left(\mathrm{C}-1_{\mathrm{B}}\right), 98.2\left(\mathrm{C}-1_{\mathrm{A}}\right)$ in ${ }^{13} \mathrm{C}$ NMR spectra]. Although, the $\mathrm{C}-3$ hydroxyl group is quite congested for the glycosylation reaction, the $\alpha$-glycosidic linkage was formed in compound $\mathbf{1 2}$ with satisfactory yield without formation of the other stereoisomer. Stereoselective glycosylation of compound 12 with D-glucose derived thioglycoside donor $\mathbf{4}$ in the presence of a combination ${ }^{19 a, 24}$ of $\mathrm{NIS}$ and $\mathrm{HClO}_{4}-\mathrm{SiO}_{2}$ produced trisaccharide derivative $\mathbf{1 3}$, which was immediately de-O-acetylated using sodium methoxide to furnish trisaccharide acceptor 14 in 73\% yield. The formation of new glycosyl linkages in compound $\mathbf{1 4}$ was confirmed from its NMR spectroscopic analysis [signals at $\delta=5.75\left(\mathrm{~d}, J=8.5 \mathrm{~Hz}, \mathrm{H}-1_{\mathrm{A}}\right), 5.66(\mathrm{~s}, \mathrm{PhCH}), 5.42(\mathrm{~d}, J=3.5$ $\left.\mathrm{Hz}, \mathrm{H}-1_{\mathrm{B}}\right), 4.62$ (br s, H-1 $1_{\mathrm{C}}$ ) in ${ }^{1} \mathrm{H}$ NMR and $\delta=101.7(\mathrm{PhCH})$, 99.4 (C-1 $\mathrm{C}), 98.8\left(\mathrm{C}-1_{\mathrm{B}}\right), 98.1\left(\mathrm{C}-1_{\mathrm{A}}\right)$ in ${ }^{13} \mathrm{C}$ NMR spectra]. NIS and $\mathrm{HClO}_{4}-\mathrm{SiO}_{2}$ mediated ${ }^{19 a, 24}$ stereoselective glycosylation of trisaccharide 14 with 3-azido-3-deoxy-D-fucosyl thioglycoside derivative $\mathbf{5}$ furnished tetrasaccharide derivative $\mathbf{1 5}$ in 63\% yield. NMR spectroscopic analysis of compound $\mathbf{1 5}$ confirmed it stereoselective formation [signals at $\delta=5.67$ $\left(\mathrm{d}, J=8.0 \mathrm{~Hz}, \mathrm{H}-1_{\mathrm{A}}\right), 5.58(\mathrm{~s}, \mathrm{PhCH}), 5.44\left(\mathrm{~d}, J=3.0 \mathrm{~Hz}, \mathrm{H}-1_{\mathrm{B}}\right)$, 4.67 (br s, $\left.\mathrm{H}-1_{\mathrm{C}}\right), 4.01$ (d, $\left.J=8.0 \mathrm{~Hz}, \mathrm{H}-1_{\mathrm{D}}\right)$ in ${ }^{1} \mathrm{H}$ NMR and $\delta=$ $101.6(\mathrm{PhCH}), 100.2\left(\mathrm{C}-1_{\mathrm{D}}\right), 99.4\left(\mathrm{C}-1_{\mathrm{C}}\right), 99.0\left(\mathrm{C}-1_{\mathrm{B}}\right), 98.2(\mathrm{C}-$ $\left.1_{A}\right)$ in ${ }^{13} \mathrm{C}$ NMR spectra]. De-O-acetylation of compound 15 by treatment with sodium methoxide furnished tetrasaccharide acceptor 16 in $84 \%$ yield, which was characterized by its NMR spectral analysis. Compound $\mathbf{1 6}$ was allowed to couple stereoselectively with D-glucose thioglycoside derivative $\mathbf{6}$ in the presence of a combination ${ }^{19 a, 24}$ of NIS and $\mathrm{HClO}_{4}-\mathrm{SiO}_{2}$ to furnish pentasaccharide derivative 17 in 64\% yield. The formation of new glycosyl linkages in compound 17 was confirmed from its NMR spectroscopic analysis [signals at $\delta=5.52\left(\mathrm{~d}, J=8.0 \mathrm{~Hz}, \mathrm{H}-1_{\mathrm{A}}\right), 4.95\left(\mathrm{~d}, J=3.0 \mathrm{~Hz}, \mathrm{H}-1_{\mathrm{B}}\right)$, $4.65\left(\mathrm{~d}, J=3.0 \mathrm{~Hz}, \mathrm{H}-1_{\mathrm{C}}\right), 4.00-3.98\left(2 \mathrm{~d}, J=8.0 \mathrm{~Hz}, \mathrm{H}-1_{\mathrm{D}}, \mathrm{H}-\right.$ $\left.1_{\mathrm{E}}\right)$ in ${ }^{1} \mathrm{H}$ NMR and $\delta=100.5\left(\mathrm{C}-1_{\mathrm{E}}\right), 100.4\left(\mathrm{C}-1_{\mathrm{D}}\right), 99.4\left(\mathrm{C}-1_{\mathrm{C}}\right)$, $98.9\left(\mathrm{C}-1_{\mathrm{B}}\right), 98.1\left(\mathrm{C}-1_{\mathrm{A}}\right)$ in ${ }^{13} \mathrm{C}$ NMR spectra]. Compound 17 was subjected to a series of functional group transformations, which include (i) treatment with hydrazine hydrate monohydrate to remove phthaloyl group; ${ }^{36}$ (ii) $\mathrm{N}$ - and $\mathrm{O}$ acetylation using acetic anhydride and pyridine; (iii) transformation of the azido group into an acetamido group by treatment with thioacetic acid in pyridine; ${ }^{37}$ (iv) de-Oacetylation using sodium methoxide; and finally (v) removal of benzyl ethers and benzylidene acetal by hydrogenolysis using hydrogen gas in the presence of Pearlman's catalyst $^{38}$ to give target pentasaccharide 1 as its $p$-methoxyphenyl glycoside in 52\% over all yield. NMR spectroscopic analysis of compound $\mathbf{1}$ unambiguously supported its formation (signals at $\delta 5.25$ (br s, H-1 ${ }_{C}$ ), 4.97 (br s, H- $1_{\mathrm{B}}$ ), 4.95 $\left(\mathrm{d}, J=9.5 \mathrm{~Hz}, \mathrm{H}-1_{\mathrm{A}}\right), 4.52$ (d, $\left.J=9.0 \mathrm{~Hz}, \mathrm{H}-1_{\mathrm{D}}\right), 4.32$ (d, $J=9.0$
$\left.\mathrm{Hz}, 1 \mathrm{H}, \mathrm{H}-1_{\mathrm{E}}\right)$ in ${ }^{1} \mathrm{H}$ NMR and $\delta=102.8\left(\mathrm{C}-1_{\mathrm{D}}\right), 102.6\left(\mathrm{C}-1_{\mathrm{E}}\right)$, $101.1\left(\mathrm{C}-1_{\mathrm{A}}\right), 101.0\left(\mathrm{C}-1_{\mathrm{B}}\right), 98.9\left(\mathrm{C}-1_{\mathrm{C}}\right)$ in ${ }^{13} \mathrm{C}$ NMR spectra] (Scheme 2).

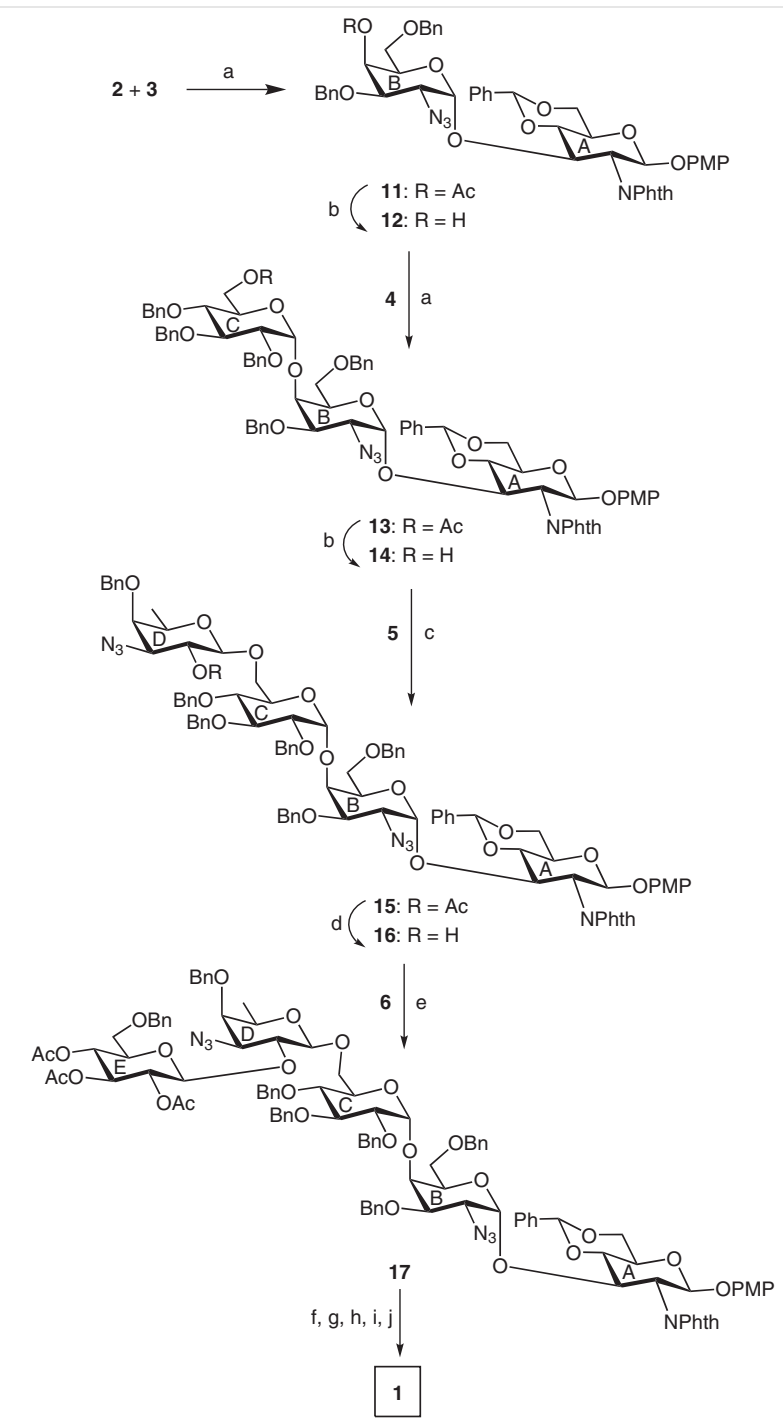

Scheme 2 Reagents and conditions: (a) $\mathrm{NIS}, \mathrm{HClO}_{4}-\mathrm{SiO}_{2}, \mathrm{CH}_{2} \mathrm{Cl}_{2},-10{ }^{\circ} \mathrm{C}$, $2 \mathrm{~h}$; (b) $0.01 \mathrm{M} \mathrm{CH}_{3} \mathrm{ONa}, \mathrm{CH}_{3} \mathrm{OH}$, r.t., $1 \mathrm{~h}, 69 \%$ for compound 12 (2 steps), $73 \%$ for compound 14 (2 steps); (c) $\mathrm{NIS}, \mathrm{HClO}_{4}-\mathrm{SiO}_{2}, \mathrm{CH}_{2} \mathrm{Cl}_{2},-70{ }^{\circ} \mathrm{C}, 3 \mathrm{~h}$, 63\%; (d) $0.01 \mathrm{M} \mathrm{CH}_{3} \mathrm{ONa}, \mathrm{CH}_{3} \mathrm{OH}$, r.t., 1 h, $84 \%$; (e) $\mathrm{NIS} \mathrm{HClO}_{4}-\mathrm{SiO}_{2}$, $\mathrm{CH}_{2} \mathrm{Cl}_{2},-20^{\circ} \mathrm{C}, 3 \mathrm{~h} ; 64 \%$; (f) $\mathrm{NH}_{2} \mathrm{NH}_{2} \cdot \mathrm{H}_{2} \mathrm{O}, \mathrm{EtOH}, 80^{\circ} \mathrm{C}, 12 \mathrm{~h}$; (g) $\mathrm{Ac}_{2} \mathrm{O}$, pyridine, r.t., $4 \mathrm{~h}$; (h) $\mathrm{CH}_{3} \mathrm{COSH}$, pyridine, r.t., $12 \mathrm{~h}$; (i) $0.1 \mathrm{M} \mathrm{CH}_{3} \mathrm{ONa}$, $\mathrm{CH}_{3} \mathrm{OH}$, r.t., 6 h; (j) $\mathrm{H}_{2}, 20 \% \mathrm{Pd}(\mathrm{OH})_{2}-\mathrm{C}, \mathrm{CH}_{3} \mathrm{OH}$, r.t., 24 h, $52 \%$ (5 steps).

In summary, a pentasaccharide repeating unit of the 0 specific polysaccharide of Salmonella enterica 055 containing 3-acetamido-3-deoxy-D-fucose moiety has been synthesized in very good yield using a sequential glycosylations strategy. To the best of our knowledge, a suitably functionalized 3-azido-3-deoxy-D-fucose thioglycoside derivative was prepared in excellent yield and used in the stereoselective glycosylation reaction for the first time. A com- 
bination of $\mathrm{NIS}$ and $\mathrm{HClO}_{4}-\mathrm{SiO}_{2}$ has been used as the thiophilic activator for the stereoselective glycosylations of thioglycosides in generalized reaction conditions. The yields of the glycosylation steps were very good with excellent stereo outcome.

All reactions were monitored by TLC over silica gel coated TLC plates. The spots on TLC were visualized by warming ceric sulfate $(2 \%$ $\mathrm{Ce}\left(\mathrm{SO}_{4}\right)_{2}$ in $2 \mathrm{~N} \mathrm{H}_{2} \mathrm{SO}_{4}$ ) sprayed plates on a hot plate. Silica gel 230400 mesh was used for column chromatography. NMR spectra were recorded on Bruker Avance $500 \mathrm{MHz}$ using $\mathrm{CDCl}_{3}$ as solvent and TMS as internal reference unless stated otherwise. MS were recorded on a Bruker mass spectrometer. Optical rotations were recorded in a Jasco P-2000 spectrometer at $25{ }^{\circ} \mathrm{C}$. Commercially available grades of organic solvents of adequate purity are used in all reactions. $\mathrm{HClO}_{4}-\mathrm{SiO}_{2}$ was prepared following the reported method. ${ }^{25}$

\section{p-Methylphenyl 4-0-Benzyl-2-0-benzoyl-1-thio- $\beta$-D-fucopyrano- side (8)}

To a solution of 7 ( $3 \mathrm{~g}, 8.02 \mathrm{mmol})$ in $\mathrm{CH}_{3} \mathrm{OH}(45 \mathrm{~mL})$ was added $\mathrm{Bu}_{2} \mathrm{SnO}(2.4 \mathrm{~g}, 9.62 \mathrm{mmol})$ and the mixture was stirred at $80^{\circ} \mathrm{C}$ for 3 $\mathrm{h}$. The solvents were evaporated and co-evaporated with toluene $(3 \times$ $30 \mathrm{~mL}$ ) under reduced pressure. To a solution of the crude product in dry DMF $(20 \mathrm{~mL})$ were added PMBCl $(1.2 \mathrm{~mL}, 8.82 \mathrm{mmol})$ and TBAB $(2.25 \mathrm{~g})$ and the mixture was stirred at $65^{\circ} \mathrm{C}$ for $6 \mathrm{~h}$. The mixture was diluted with $\mathrm{H}_{2} \mathrm{O}(100 \mathrm{~mL})$ and extracted with EtOAc $(100 \mathrm{~mL})$. The organic layer was successively washed with $2 \mathrm{M} \mathrm{HCl}(50 \mathrm{~mL})$ and $\mathrm{H}_{2} \mathrm{O}$ $(50 \mathrm{~mL})$, dried $\left(\mathrm{Na}_{2} \mathrm{SO}_{4}\right)$, and concentrated. To a solution of the crude product in DMF ( $20 \mathrm{~mL}$ ) was added $\mathrm{NaH}(60 \%$ oil coated; $300 \mathrm{mg}$ ) and the mixture was stirred at $0{ }^{\circ} \mathrm{C}$. To the stirred solution was added benzyl bromide $(1.1 \mathrm{~mL}, 9.25 \mathrm{mmol})$ and the mixture was stirred at r.t. for $2 \mathrm{~h}$. The mixture was quenched with aq $\mathrm{NH}_{4} \mathrm{Cl}$, diluted with $\mathrm{H}_{2} \mathrm{O}$ $(50 \mathrm{~mL})$, and extracted with $\mathrm{CH}_{2} \mathrm{Cl}_{2}(100 \mathrm{~mL})$. The organic layer was washed with $\mathrm{H}_{2} \mathrm{O}(50 \mathrm{~mL})$, dried $\left(\mathrm{Na}_{2} \mathrm{SO}_{4}\right)$, and concentrated under reduced pressure. To a solution of the crude product in $\mathrm{CH}_{2} \mathrm{Cl}_{2}(27 \mathrm{~mL})$ was added a solution of DDQ $(1.3 \mathrm{~g}, 5.64 \mathrm{mmol})$ in $\mathrm{H}_{2} \mathrm{O}(3 \mathrm{~mL})$ and the biphasic mixture was stirred at r.t. for $3 \mathrm{~h}$. The mixture was diluted with $\mathrm{H}_{2} \mathrm{O}(50 \mathrm{~mL})$ and extracted with $\mathrm{CH}_{2} \mathrm{Cl}_{2}(50 \mathrm{~mL})$. The organic layer was washed with $\mathrm{H}_{2} \mathrm{O}(50 \mathrm{~mL})$, dried $\left(\mathrm{Na}_{2} \mathrm{SO}_{4}\right)$, and concentrated. The obtained crude was purified by column chromatography (silica gel, hexane/EtOAc 3:1) to give pure $\mathbf{8}(2.68 \mathrm{~g}, 72 \%)$ as a colorless oil.

$[\alpha]_{D}-7.0\left(c 1.0, \mathrm{CHCl}_{3}\right)$.

${ }^{1} \mathrm{H}$ NMR $\left(500 \mathrm{MHz}, \mathrm{CDCl}_{3}\right): \delta=7.99-6.96(\mathrm{~m}, 14 \mathrm{H}, \mathrm{Ar}-H), 5.10(\mathrm{t}, J=$ $10.0 \mathrm{~Hz}, 1 \mathrm{H}, \mathrm{H}-2), 4.72$ (br s, $\left.2 \mathrm{H}, \mathrm{CH}_{2} \mathrm{Ph}\right), 4.62(\mathrm{~d}, J=10.0 \mathrm{~Hz}, 1 \mathrm{H}, \mathrm{H}-$ 1), 3.72 (m, $1 \mathrm{H}, \mathrm{H}-5$ ), 3.61-3.58 (m, $2 \mathrm{H}, \mathrm{H}-3, \mathrm{H}-4), 2.25$ (s, $3 \mathrm{H}, \mathrm{CH}_{3}$ ), $1.30\left(\mathrm{~d}, J=6.5 \mathrm{~Hz}, 3 \mathrm{H}, \mathrm{CCH}_{3}\right)$.

${ }^{13} \mathrm{C} \mathrm{NMR}\left(125 \mathrm{MHz}, \mathrm{CDCl}_{3}\right): \delta=166.6(\mathrm{COPh}), 138.1-127.6(\mathrm{Ar}-\mathrm{C}), 85.9$ (C-1), $80.1(\mathrm{C}-3), 75.9\left(\mathrm{CH}_{2} \mathrm{Ph}\right), 74.9(\mathrm{C}-5, \mathrm{C}-4), 72.3(\mathrm{C}-2), 21.2\left(\mathrm{CH}_{3}\right)$, $17.2\left(\mathrm{CCH}_{3}\right)$.

HRMS (ESI): $m / z[\mathrm{M}+\mathrm{H}]^{+}$calcd for $\mathrm{C}_{27} \mathrm{H}_{28} \mathrm{O}_{5} \mathrm{~S}$ (464.1657): 465.1735; found: 465.1721 .

\section{p-Methylphenyl 4-0-Benzyl-1-thio- $\beta$-D-gulopyranoside (9)}

A solution of compound $8(1.8 \mathrm{~g}, 3.87 \mathrm{mmol})$ in dry $\mathrm{CH}_{2} \mathrm{Cl}_{2}(25 \mathrm{~mL})$ was cooled to $10^{\circ} \mathrm{C}$. To the cooled reaction mixture were added pyridine $(1 \mathrm{~mL})$ and $\mathrm{Tf}_{2} \mathrm{O}(715 \mu \mathrm{L}, 4.26 \mathrm{mmol})$ and it was stirred at same temperature for $2 \mathrm{~h}$. The solvents were removed and co-evaporated with toluene $(2 \times 20 \mathrm{~mL})$ under reduced pressure. To a solution of the crude product in dry DMF $(10 \mathrm{~mL})$ was added NaNO2 $(2 \mathrm{~g}, 29 \mathrm{mmol})$ and it was stirred at $60{ }^{\circ} \mathrm{C}$ for $12 \mathrm{~h}$. The reaction mixture was diluted with $\mathrm{H}_{2} \mathrm{O}(50 \mathrm{~mL})$ and extracted with $\mathrm{CH}_{2} \mathrm{Cl}_{2}(50 \mathrm{~mL})$. The organic layer was washed with water $(50 \mathrm{~mL})$, dried $\left(\mathrm{Na}_{2} \mathrm{SO}_{4}\right)$ and concentrated. A solution of the crude product in $0.1 \mathrm{M} \mathrm{CH}_{3} \mathrm{ONa}$ in $\mathrm{CH}_{3} \mathrm{OH}(10 \mathrm{~mL})$ was stirred at room temperature for $3 \mathrm{~h}$, neutralized with Amberlite IR-120 $(\mathrm{H}+)$ resin, filtered and concentrated to give compound 9 (910 $\mathrm{mg}, 65 \%)$ as a colorless oil.

$[\alpha]_{\mathrm{D}}-12.0\left(\right.$ c $\left.1.0, \mathrm{CHCl}_{3}\right)$.

${ }^{1} \mathrm{H}$ NMR $\left(500 \mathrm{MHz}, \mathrm{CDCl}_{3}\right): \delta=7.36-7.01(\mathrm{~m}, 9 \mathrm{H}, \mathrm{Ar}-\mathrm{H}), 4.71(\mathrm{~d}, J=$ $10.0 \mathrm{~Hz}, 1 \mathrm{H}, \mathrm{H}-1), 4.59$ (d, $\left.J=12.0 \mathrm{~Hz}, 1 \mathrm{H}, \mathrm{CH}_{2} \mathrm{Ph}\right), 4.48(\mathrm{~d}, J=12.0 \mathrm{~Hz}$, $1 \mathrm{H}, \mathrm{CH}_{2} \mathrm{Ph}$ ), 4.14-4.13 (m, $\left.1 \mathrm{H}, \mathrm{H}-5\right), 3.96-3.95$ (m, $\left.1 \mathrm{H}, \mathrm{H}-3\right), 3.67$ (dd, $J=10.0,3.5 \mathrm{~Hz}, 1 \mathrm{H}, \mathrm{H}-2), 3.30(\mathrm{~d}, J=2.5 \mathrm{~Hz}, 1 \mathrm{H}, \mathrm{H}-4), 2.27(\mathrm{~s}, 3 \mathrm{H}$, $\left.\mathrm{CH}_{3}\right), 1.19\left(\mathrm{~d}, J=6.5 \mathrm{~Hz}, 3 \mathrm{H}, \mathrm{CCH}_{3}\right)$.

${ }^{13} \mathrm{C}$ NMR $\left(125 \mathrm{MHz}, \mathrm{CDCl}_{3}\right): \delta=138.0-126.9(\mathrm{Ar}-\mathrm{C}), 86.0(\mathrm{C}-1), 78.0$ (C-3), $72.8\left(\mathrm{CH}_{2} \mathrm{Ph}\right), 71.7$ (C-4), 67.5 (C-5), $66.9(\mathrm{C}-2), 21.2\left(\mathrm{CH}_{3}\right), 16.4$ $\left(\mathrm{CCH}_{3}\right)$.

HRMS (ESI): $m / z[\mathrm{M}+\mathrm{H}]^{+}$calcd for $\mathrm{C}_{20} \mathrm{H}_{24} \mathrm{O}_{4} \mathrm{~S}$ (360.1395): 361.1473; found: 361.1460 .

\section{p-Methylphenyl 4-0-Benzyl-2-0-naphthylmethyl-1-thio- $\beta$-D-gu- lopyranoside (10)}

To a solution of $\mathbf{9}$ (900 mg, $2.50 \mathrm{mmol})$ in $\mathrm{CH}_{3} \mathrm{OH}(30 \mathrm{~mL})$ was added $\mathrm{Bu}_{2} \mathrm{SnO}(750 \mathrm{mg}, 3.0 \mathrm{mmol})$ and the mixture was stirred at $80^{\circ} \mathrm{C}$ for 3 $\mathrm{h}$. The solvents were evaporated and co-evaporated with toluene $(3 \times$ $20 \mathrm{~mL}$ ) under reduced pressure. To a solution of the crude product in dry DMF $(10 \mathrm{~mL})$ were added 2-(bromomethyl)naphthalene $(610 \mathrm{mg}$, $2.75 \mathrm{mmol}$ ) and $\mathrm{CsF}$ (380 $\mathrm{mg}, 2.5 \mathrm{mmol}$ ) and the mixture was stirred at $65{ }^{\circ} \mathrm{C}$ for $6 \mathrm{~h}$. The mixture was diluted with $\mathrm{H}_{2} \mathrm{O}(50 \mathrm{~mL})$ and extracted with EtOAc $(50 \mathrm{~mL})$. The organic layer was successively washed with $2 \mathrm{M} \mathrm{HCl}(50 \mathrm{~mL})$ and $\mathrm{H}_{2} \mathrm{O}(50 \mathrm{~mL})$, dried $\left(\mathrm{Na}_{2} \mathrm{SO}_{4}\right)$, and concentrated. The crude product was purified by column chromatography (silica gel, hexane/EtOAc 2:1) to give pure $\mathbf{1 0}(1.0 \mathrm{~g}, 80 \%)$ as a colorless oil.

$[\alpha]_{\mathrm{D}}-17.0\left(\right.$ c $\left.1.0, \mathrm{CHCl}_{3}\right)$.

${ }^{1} \mathrm{H}$ NMR $\left(500 \mathrm{MHz}, \mathrm{CDCl}_{3}\right): \delta=7.50-7.07(\mathrm{~m}, 16 \mathrm{H}, \mathrm{Ar}-\mathrm{H}), 4.95(\mathrm{~d}, J=$ $10.0 \mathrm{~Hz}, 1 \mathrm{H}, \mathrm{H}-1), 4.89\left(\mathrm{~d}, J=10.0 \mathrm{~Hz}, 1 \mathrm{H}, \mathrm{CH}_{2} \mathrm{Ph}\right), 4.68$ (d, $J=11.5 \mathrm{~Hz}$, $\left.1 \mathrm{H}, \mathrm{CH}_{2} \mathrm{Ph}\right), 4.44-4.43\left(\mathrm{~m}, 2 \mathrm{H}, \mathrm{CH}_{2} \mathrm{Ph}\right), 4.03-4.00(\mathrm{~m}, 2 \mathrm{H}, \mathrm{H}-3, \mathrm{H}-5)$, 3.76 (dd, $J=10.0,3.0 \mathrm{~Hz}, 1 \mathrm{H}, \mathrm{H}-2$ ), 3.35 (d, $J=2.5 \mathrm{~Hz}, 1 \mathrm{H}, \mathrm{H}-4), 2.37$ (s, $\left.3 \mathrm{H}, \mathrm{CH}_{3}\right), 1.27$ (d, $J=6.5 \mathrm{~Hz}, 3 \mathrm{H}, \mathrm{CCH}_{3}$ ).

${ }^{13} \mathrm{C}$ NMR $\left(125 \mathrm{MHz}, \mathrm{CDCl}_{3}\right): \delta=132.2-125.9(\mathrm{Ar}-\mathrm{C}), 83.9(\mathrm{C}-1), 78.0$ (C-3), 73.7 (C-4), $73.1\left(\mathrm{CH}_{2} \mathrm{Ph}\right), 72.9\left(\mathrm{CH}_{2} \mathrm{Ph}\right), 71.1(\mathrm{C}-5), 67.1(\mathrm{C}-2)$, $21.2\left(\mathrm{CH}_{3}\right), 16.3\left(\mathrm{CCH}_{3}\right)$.

HRMS (ESI): $m / z[\mathrm{M}+\mathrm{H}]^{+}$calcd for $\mathrm{C}_{31} \mathrm{H}_{32} \mathrm{O}_{4} \mathrm{~S}$ (500.2021): 501.2099; found: 501.2082 .

\section{p-Methylphenyl 2-0-Acetyl-3-azido-4-0-benzyl-3-deoxy-1-thio- $\beta$ - D-fucopyranoside (5)}

A solution of $\mathbf{1 0}(1.0 \mathrm{~g}, 2.0 \mathrm{mmol})$ in dry $\mathrm{CH}_{2} \mathrm{Cl}_{2}(15 \mathrm{~mL})$ was cooled to $-10{ }^{\circ} \mathrm{C}$. To the cooled mixture were added pyridine $(0.5 \mathrm{~mL})$ and $\mathrm{Tf}_{2} \mathrm{O}$ $(850 \mu \mathrm{L}, 5.06 \mathrm{mmol})$ and it was stirred at $-10{ }^{\circ} \mathrm{C}$ for $2 \mathrm{~h}$. The solvents were removed and co-evaporated with toluene $(2 \times 20 \mathrm{~mL})$ under reduced pressure. To a solution of the crude product in dry DMF $(5 \mathrm{~mL})$ was added $\mathrm{NaN}_{3}(1.5 \mathrm{~g}, 23 \mathrm{mmol})$ and it was stirred at $60{ }^{\circ} \mathrm{C}$ for $12 \mathrm{~h}$. The mixture was diluted with $\mathrm{H}_{2} \mathrm{O}(50 \mathrm{~mL})$ and extracted with $\mathrm{CH}_{2} \mathrm{Cl}_{2}$ $(50 \mathrm{~mL})$. The organic layer was washed with water $(50 \mathrm{~mL})$, dried $\left(\mathrm{Na}_{2} \mathrm{SO}_{4}\right)$, and concentrated. To a solution of the crude product in $\mathrm{CH}_{2} \mathrm{Cl}_{2}(20 \mathrm{~mL})$ was added a solution of DDQ $(900 \mathrm{mg}, 4.0 \mathrm{mmol})$ in $\mathrm{H}_{2} \mathrm{O}(2 \mathrm{~mL})$ and the biphasic mixture was stirred at r.t. for $3 \mathrm{~h}$. The 
mixture was diluted with $\mathrm{H}_{2} \mathrm{O}(50 \mathrm{~mL})$ and extracted with $\mathrm{CH}_{2} \mathrm{Cl}_{2}(50$ $\mathrm{mL})$. The organic layer was washed with $\mathrm{H}_{2} \mathrm{O}(50 \mathrm{~mL})$, dried $\left(\mathrm{Na}_{2} \mathrm{SO}_{4}\right)$, and concentrated. To a solution of the crude product in pyridine ( 5 $\mathrm{mL})$ was added $\mathrm{Ac}_{2} \mathrm{O}(2 \mathrm{~mL})$ and the mixture was stirred at r.t. for $3 \mathrm{~h}$. The mixture was concentrated under reduced pressure and co-evaporated with toluene $(3 \times 20 \mathrm{~mL})$. The crude product was purified by column chromatography (silica gel, hexane/EtOAc 3:1) to give pure $\mathbf{5}$ (555 mg, 65\%) as a colorless oil.

$[\alpha]_{\mathrm{D}}-10.0\left(\mathrm{c} 1.0, \mathrm{CHCl}_{3}\right)$.

${ }^{1} \mathrm{H}$ NMR $\left(500 \mathrm{MHz}, \mathrm{CDCl}_{3}\right): \delta=7.32-6.98(\mathrm{~m}, 9 \mathrm{H}, \mathrm{Ar}-\mathrm{H}), 5.23(\mathrm{t}, J=5.0$ $\mathrm{Hz}, 1 \mathrm{H}, \mathrm{H}-2), 4.85\left(\mathrm{~d}, J=11.5 \mathrm{~Hz}, 1 \mathrm{H}, \mathrm{CH}_{2} \mathrm{Ph}\right), 4.53(\mathrm{~d}, J=11.5 \mathrm{~Hz}, 1 \mathrm{H}$, $\mathrm{CH}_{2} \mathrm{Ph}$ ), 4.47 (d, $J=10.0 \mathrm{~Hz}, 1 \mathrm{H}, \mathrm{H}-1$ ), 3.54-3.47 (m, $2 \mathrm{H}, \mathrm{H}-4, \mathrm{H}-5$ ), 3.41 (dd, $J=10.5,3.0 \mathrm{~Hz}, 1 \mathrm{H}, \mathrm{H}-3), 2.26\left(\mathrm{~s}, 3 \mathrm{H}, \mathrm{CH}_{3}\right), 2.08(\mathrm{~s}, 3 \mathrm{H}$, $\left.\mathrm{COCH}_{3}\right), 1.17\left(\mathrm{~d}, J=6.5 \mathrm{~Hz}, 3 \mathrm{H}, \mathrm{CCH}_{3}\right)$.

${ }^{13} \mathrm{C} \mathrm{NMR}\left(125 \mathrm{MHz}, \mathrm{CDCl}_{3}\right): \delta=170.1\left(\mathrm{COCH}_{3}\right), 132.9-128.0(\mathrm{Ar}-\mathrm{C})$, 86.8 (C-1), 77.9 (C-3), $75.4\left(\mathrm{CH}_{2} \mathrm{Ph}\right), 75.3$ (C-4), 68.7 (C-5), 65.2 (C-2), $21.2\left(\mathrm{CH}_{3}\right), 20.9\left(\mathrm{COCH}_{3}\right), 17.0\left(\mathrm{CCH}_{3}\right)$.

HRMS (ESI): $m / z[\mathrm{M}+\mathrm{H}]^{+}$calcd for $\mathrm{C}_{22} \mathrm{H}_{25} \mathrm{~N}_{3} \mathrm{O}_{4} \mathrm{~S}$ (427.1566): 428.1644; found: 428.1656.

\section{p-Methoxyphenyl (2-Azido-3,6-di-O-benzyl-2-deoxy- $\alpha$-D-galacto- pyranosyl)-(1 $\rightarrow 3)-4,6-0$-benzylidene-2-deoxy-2- $N$-phthalimido- $\beta$-D-glucopyranoside (12)}

To a solution of $2(1.5 \mathrm{~g}, 2.98 \mathrm{mmol})$ and $\mathbf{3}(1.85 \mathrm{~g}, 3.57 \mathrm{mmol})$ in anhyd $\mathrm{CH}_{2} \mathrm{Cl}_{2}(10 \mathrm{~mL})$ was added MS $4 \AA$ ( $\left.1.5 \mathrm{~g}\right)$ and the mixture was cooled to $-10{ }^{\circ} \mathrm{C}$ under argon. To the cooled mixture were added NIS $(880 \mathrm{mg}, 3.90 \mathrm{mmol})$ and $\mathrm{HClO}_{4}-\mathrm{SiO}_{2}(50 \mathrm{mg})$ and it was stirred at $-10{ }^{\circ} \mathrm{C}$ for $2 \mathrm{~h}$. The mixture was filtered through a Celite bed and washed with $\mathrm{CH}_{2} \mathrm{Cl}_{2}(50 \mathrm{~mL})$. The combined organic layers were successively washed with $5 \% \mathrm{Na}_{2} \mathrm{~S}_{2} \mathrm{O}_{3}(50 \mathrm{~mL})$, sat. $\mathrm{NaHCO}_{3}(50 \mathrm{~mL})$, and $\mathrm{H}_{2} \mathrm{O}(50 \mathrm{~mL})$, dried $\left(\mathrm{Na}_{2} \mathrm{SO}_{4}\right)$, passed through a short pad of silica gel, and concentrated. A solution of the disaccharide derivative in $0.01 \mathrm{M}$ $\mathrm{CH}_{3} \mathrm{ONa}$ in $\mathrm{CH}_{3} \mathrm{OH}(30 \mathrm{~mL}$ ) was stirred at r.t. for $1 \mathrm{~h}$, neutralized with Amberlite IR-120 $\left(\mathrm{H}^{+}\right)$resin, filtered, and concentrated. The crude product was purified by column chromatography (silica gel, hexane/EtOAc 2:1) to give pure $\mathbf{1 2}(1.8 \mathrm{~g}, 69 \%)$ as a colorless oil.

$[\alpha]_{D}-23\left(c 1.0, \mathrm{CHCl}_{3}\right)$.

${ }^{1} \mathrm{H}$ NMR $\left(500 \mathrm{MHz}, \mathrm{CDCl}_{3}\right): \delta=7.55-6.45(\mathrm{~m}, 23 \mathrm{H}, \mathrm{Ar}-\mathrm{H}), 5.74(\mathrm{~d}, J=$ $\left.8.5 \mathrm{~Hz}, 1 \mathrm{H}, \mathrm{H}-1_{\mathrm{A}}\right), 5.64(\mathrm{~s}, 1 \mathrm{H}, \mathrm{PhCH}), 5.37$ (d, J = 3.5 Hz, $1 \mathrm{H}, \mathrm{H}-1_{\mathrm{B}}$ ), $4.80\left(\mathrm{t}, J=9.0 \mathrm{~Hz}, 1 \mathrm{H}, \mathrm{H}-3_{\mathrm{A}}\right), 4.69\left(\mathrm{~d}, J=11.5 \mathrm{~Hz}, 1 \mathrm{H}, \mathrm{CH}_{2} \mathrm{Ph}\right), 4.64(\mathrm{~d}$, $\left.J=11.5 \mathrm{~Hz}, 1 \mathrm{H}, \mathrm{CH}_{2} \mathrm{Ph}\right), 4.57\left(\mathrm{t}, J=8.5 \mathrm{~Hz}, 1 \mathrm{H}, \mathrm{H}-2_{\mathrm{A}}\right), 4.41$ (dd, $J=10.5$, $\left.5 \mathrm{~Hz}, 1 \mathrm{H}, \mathrm{H}-6_{\mathrm{aA}}\right), 4.12$ (d, J = $12.0 \mathrm{~Hz}, 1 \mathrm{H}, \mathrm{CH}_{2} \mathrm{Ph}$ ), 4.04 (d, $J=12.0 \mathrm{~Hz}$, $1 \mathrm{H}, \mathrm{CH}_{2} \mathrm{Ph}$ ), 3.99 (t, $J=9.5 \mathrm{~Hz}, 1 \mathrm{H}, \mathrm{H}-4_{\mathrm{A}}$ ), 3.88 (t, $J=10.5 \mathrm{~Hz}, 1 \mathrm{H}, \mathrm{H}-$ $\left.6_{\mathrm{bA}}\right), 3.82\left(\mathrm{~s}, 1 \mathrm{H}, \mathrm{H}-4_{\mathrm{B}}\right), 3.77\left(\mathrm{dd}, J=10.5,5.0 \mathrm{~Hz}, 1 \mathrm{H}, \mathrm{H}-3_{\mathrm{B}}\right), 3.74-3.72$ $\left(\mathrm{m}, 1 \mathrm{H}, \mathrm{H}-5_{\mathrm{A}}\right), 3.70\left(\mathrm{~s}, 3 \mathrm{H}, \mathrm{OCH}_{3}\right), 3.57$ (dd, $\left.J=11.0,4.0 \mathrm{~Hz}, 1 \mathrm{H}, \mathrm{H}-2_{\mathrm{B}}\right)$, $3.40\left(\mathrm{t}, J=6.0 \mathrm{~Hz}, 1 \mathrm{H}, \mathrm{H}-5_{\mathrm{B}}\right), 3.22\left(\mathrm{t}, J=9.5,2.0 \mathrm{~Hz}, 1 \mathrm{H}, \mathrm{H}-6_{\mathrm{aB}}\right), 2.71$ (dd, $J=10,4.0 \mathrm{~Hz}, 1 \mathrm{H}, \mathrm{H}-6_{\mathrm{bB}}$ ).

${ }^{13} \mathrm{C}$ NMR (125 MHz, $\left.\mathrm{CDCl}_{3}\right): \delta=155.7-114.5(\mathrm{Ar}-\mathrm{C}), 101.5(\mathrm{PhCH}), 98.6$ $\left(\mathrm{C}-1_{\mathrm{B}}\right), 98.2\left(\mathrm{C}-1_{\mathrm{A}}\right), 82.3\left(\mathrm{C}-4_{\mathrm{A}}\right), 75.4\left(\mathrm{C}-4_{\mathrm{B}}\right), 74.4\left(\mathrm{C}-3_{\mathrm{A}}\right), 73.1\left(\mathrm{CH}_{2} \mathrm{Ph}\right)$, $72.0\left(\mathrm{CH}_{2} \mathrm{Ph}\right), 68.9\left(\mathrm{C}-5_{\mathrm{B}}\right), 68.6\left(\mathrm{C}-6_{\mathrm{B}}\right), 68.4\left(\mathrm{C}-6_{\mathrm{A}}\right), 66.1\left(\mathrm{C}-4_{\mathrm{B}}\right), 66.0(\mathrm{C}-$ $\left.5_{\mathrm{A}}\right), 58.6\left(\mathrm{C}-2_{\mathrm{B}}\right), 55.4\left(\mathrm{OCH}_{3}\right), 55.1\left(\mathrm{C}-2_{\mathrm{A}}\right)$.

HRMS (ESI): $m / z[\mathrm{M}+\mathrm{H}]^{+}$calcd for $\mathrm{C}_{48} \mathrm{H}_{46} \mathrm{~N}_{4} \mathrm{O}_{12}$ (870.3112): 871.3190; found: 871.3177 .
p-Methoxyphenyl (2,3,4-tri-O-Benzyl- $\alpha$-D-glucopyranosyl)-(1 $\rightarrow 4)$ (2-azido-3,6-di-0-benzyl-2-deoxy- $\alpha$-D-galactopyranosyl)-( $1 \rightarrow 3)$ 4,6-O-benzylidene-2-deoxy-2- $N$-phthalimido- $\beta$-D-glucopyranoside (14)

To a solution of $12(1.1 \mathrm{~g}, 1.26 \mathrm{mmol})$ and 4 (900 mg, $1.51 \mathrm{mmol})$ in anhyd $\mathrm{CH}_{2} \mathrm{Cl}_{2}(10 \mathrm{~mL})$ was added MS $4 \AA$ ( $\left.1.0 \mathrm{~g}\right)$ and the mixture was cooled to $-10{ }^{\circ} \mathrm{C}$ under argon. To the cooled mixture were added NIS ( $375 \mathrm{mg}, 1.66 \mathrm{mmol}$ ) and $\mathrm{HClO}_{4}-\mathrm{SiO}_{2}(30 \mathrm{mg}$ ) and it was stirred at $-10{ }^{\circ} \mathrm{C}$ for $2 \mathrm{~h}$. The mixture was filtered through a Celite bed and washed with $\mathrm{CH}_{2} \mathrm{Cl}_{2}(50 \mathrm{~mL})$. The combined organic layers were successively washed with $5 \% \mathrm{Na}_{2} \mathrm{~S}_{2} \mathrm{O}_{3}(50 \mathrm{~mL})$, sat. $\mathrm{NaHCO}_{3}(50 \mathrm{~mL})$, and $\mathrm{H}_{2} \mathrm{O}(50 \mathrm{~mL})$, dried $\left(\mathrm{Na}_{2} \mathrm{SO}_{4}\right)$, passed through a short pad of silica gel, and concentrated. A solution of the trisaccharide derivative in $0.01 \mathrm{M}$ $\mathrm{CH}_{3} \mathrm{ONa}$ in $\mathrm{CH}_{3} \mathrm{OH}(20 \mathrm{~mL})$ was stirred at r.t. for $1 \mathrm{~h}$, neutralized with Amberlite IR-120 $\left(\mathrm{H}^{+}\right)$resin, filtered, and concentrated. The crude product was purified by column chromatography (silica gel, hexane/EtOAc 3:1) to give pure $\mathbf{1 4}(1.2 \mathrm{~g}, 73 \%)$ as a colorless oil.

$[\alpha]_{\mathrm{D}}-21.0\left(\mathrm{c} 1.0, \mathrm{CHCl}_{3}\right)$.

${ }^{1} \mathrm{H}$ NMR $\left(500 \mathrm{MHz}, \mathrm{CDCl}_{3}\right): \delta=7.74-6.69(\mathrm{~m}, 38 \mathrm{H}, \mathrm{Ar}-\mathrm{H}), 5.75(\mathrm{~d}, J=$ $\left.8.5 \mathrm{~Hz}, 1 \mathrm{H}, \mathrm{H}-1_{\mathrm{A}}\right), 5.66(\mathrm{~s}, 1 \mathrm{H}, \mathrm{PhCH}), 5.42\left(\mathrm{~d}, J=3.5 \mathrm{~Hz}, 1 \mathrm{H}, \mathrm{H}-1_{\mathrm{B}}\right)$, 4.85-4.81 (m, $\left.3 \mathrm{H}, \mathrm{H}-3_{\mathrm{A}}, 2 \mathrm{CHPh}\right), 4.80$ (d, J = 11.5 Hz, $\left.1 \mathrm{H}, \mathrm{CHPh}\right), 4.77$ $(\mathrm{d}, J=12.0 \mathrm{~Hz}, 1 \mathrm{H}, \mathrm{CHPh}), 4.71-4.63(\mathrm{~m}, 2 \mathrm{H}, 2 \mathrm{CHPh}), 4.62$ (br s, $1 \mathrm{H}$, $\left.\mathrm{H}-1_{\mathrm{C}}\right), 4.59-4.54\left(\mathrm{~m}, 2 \mathrm{H}, \mathrm{H}-2_{\mathrm{A}}, \mathrm{CHPh}\right), 4.45-4.40\left(\mathrm{~m}, 2 \mathrm{H}, \mathrm{H}-6_{\mathrm{aA}}\right.$, $\mathrm{CHPh}), 4.00\left(\mathrm{t}, J=9.0 \mathrm{~Hz}, 1 \mathrm{H}, \mathrm{H}-4_{\mathrm{A}}\right), 3.91-3.83\left(\mathrm{~m}, 3 \mathrm{H}, \mathrm{H}-3_{\mathrm{C}}, \mathrm{H}-5_{\mathrm{C}}, \mathrm{H}-\right.$ $\left.6_{\mathrm{bA}}\right), 3.83\left(\mathrm{~s}, 1 \mathrm{H}, \mathrm{H}-4_{\mathrm{B}}\right), 3.78-3.76\left(\mathrm{~m}, 2 \mathrm{H}, \mathrm{H}-5_{\mathrm{A}}, \mathrm{H}-3_{\mathrm{B}}\right), 3.70$ (s, $3 \mathrm{H}$, $\left.\mathrm{OCH}_{3}\right), 3.67$ (d, $\left.J=12.5 \mathrm{~Hz}, 1 \mathrm{H}, \mathrm{CHPh}\right), 3.62-3.60\left(\mathrm{~m}, 2 \mathrm{H}, \mathrm{H}-2_{\mathrm{B}}, \mathrm{H}-6_{\mathrm{aB}}\right.$ ), $3.55(\mathrm{~d}, J=12.0 \mathrm{~Hz}, 1 \mathrm{H}, \mathrm{CHPh}), 3.47-3.43\left(\mathrm{~m}, 2 \mathrm{H}, \mathrm{H}-5_{\mathrm{B}}, \mathrm{H}-4_{\mathrm{C}}\right), 3.29-$ $3.27\left(\mathrm{~m}, 2 \mathrm{H}, \mathrm{H}-2_{\mathrm{c}}, \mathrm{H}-6_{\mathrm{ac}}\right), 3.20$ (d, J = $\left.10.0 \mathrm{~Hz}, 1 \mathrm{H}, \mathrm{H}-6_{\mathrm{bc}}\right), 2.59-2.56$ (m, $\left.1 \mathrm{H}, \mathrm{H}-6_{\mathrm{bB}}\right)$.

${ }^{13} \mathrm{C} \mathrm{NMR}\left(125 \mathrm{MHz}, \mathrm{CDCl}_{3}\right): \delta=155.7-114.5(\mathrm{Ar}-\mathrm{C}), 101.7(\mathrm{PhCH}), 99.4$ $\left(\mathrm{C}-1_{\mathrm{C}}\right), 98.8\left(\mathrm{C}-1_{\mathrm{B}}\right), 98.1\left(\mathrm{C}-1_{\mathrm{A}}\right), 82.4\left(\mathrm{C}-4_{\mathrm{A}}\right), 81.7\left(\mathrm{C}-3_{\mathrm{C}}\right), 80.0\left(\mathrm{C}-2_{\mathrm{C}}\right)$, $77.4\left(\mathrm{C}-4_{\mathrm{C}}\right), 75.3\left(\mathrm{CH}_{2} \mathrm{Ph}\right), 75.1\left(\mathrm{C}-4_{\mathrm{B}}\right), 74.9\left(\mathrm{CH}_{2} \mathrm{Ph}\right), 74.3\left(\mathrm{C}-3_{\mathrm{A}}\right), 74.2$ $\left(\mathrm{C}-4_{\mathrm{B}}\right), 73.7\left(\mathrm{CH}_{2} \mathrm{Ph}\right), 72.4\left(\mathrm{CH}_{2} \mathrm{Ph}\right), 72.1\left(\mathrm{CH}_{2} \mathrm{Ph}\right), 71.3\left(\mathrm{C}-5_{\mathrm{C}}\right), 69.9(\mathrm{C}-$ $\left.5_{B}\right), 68.6\left(C-6_{A}\right), 66.9\left(C-6_{B}\right), 66.1\left(C-5_{A}\right), 60.9\left(C-6_{C}\right), 59.1\left(C-2_{B}\right), 55.4$ $\left(\mathrm{OCH}_{3}\right), 55.2\left(\mathrm{C}-2_{\mathrm{A}}\right)$.

HRMS (ESI): $m / z[M+H]^{+}$calcd for $\mathrm{C}_{75} \mathrm{H}_{74} \mathrm{~N}_{4} \mathrm{O}_{17}$ (1302.5049): 1303.5127; found: 1303.5118 .

p-Methoxyphenyl (2-0-Acetyl-3-azido-4-0-benzyl-3-deoxy- $\beta$-Dfucopyranosyl)-( $1 \rightarrow 6)$-(2,3,4-tri- 0 -benzyl- $\alpha$-D-glucopyranosyl)$(1 \rightarrow 4)$-(2-azido-3,6-di-0-benzyl-2-deoxy- $\alpha$-D-galactopyranosyl)$(1 \rightarrow 3)-4,6-0$-benzylidene-2-deoxy-2- $N$-phthalimido- $\beta$-D-glucopyranoside (15)

To a solution of $\mathbf{1 4}(800 \mathrm{mg}, 0.61 \mathrm{mmol})$ and $\mathbf{5}(395 \mathrm{mg}, 0.91 \mathrm{mmol})$ in anhyd $\mathrm{CH}_{2} \mathrm{Cl}_{2}(10 \mathrm{~mL})$ was added MS $4 \AA$ ( $\left.0.5 \mathrm{~g}\right)$ and the mixture was cooled to $-70{ }^{\circ} \mathrm{C}$ under argon. To the cooled mixture were added NIS ( $225 \mathrm{mg}, 1.00 \mathrm{mmol}$ ) and $\mathrm{HClO}_{4}-\mathrm{SiO}_{2}(25 \mathrm{mg}$ ) and it was stirred at $-70{ }^{\circ} \mathrm{C}$ for $3 \mathrm{~h}$. The mixture was filtered through a Celite bed and washed with $\mathrm{CH}_{2} \mathrm{Cl}_{2}(50 \mathrm{~mL})$. The combined organic layers were successively washed with $5 \% \mathrm{Na}_{2} \mathrm{~S}_{2} \mathrm{O}_{3}(25 \mathrm{~mL})$, sat. $\mathrm{NaHCO}_{3}(25 \mathrm{~mL}), \mathrm{H}_{2} \mathrm{O}$ $(25 \mathrm{~mL})$, dried $\left(\mathrm{Na}_{2} \mathrm{SO}_{4}\right)$, and concentrated. The crude product was purified by column chromatography (silica gel, hexane/EtOAc 3:1) to give pure $\mathbf{1 5}(620 \mathrm{mg}, 63 \%)$ as a colorless oil.

$[\alpha]_{\mathrm{D}}-19.0\left(\mathrm{c} 1.0, \mathrm{CHCl}_{3}\right)$.

${ }^{1} \mathrm{H}$ NMR $\left(500 \mathrm{MHz}, \mathrm{CDCl}_{3}\right): \delta=7.97-6.65(\mathrm{~m}, 43 \mathrm{H}, \mathrm{Ar}-\mathrm{H}), 5.67(\mathrm{~d}, J=$ $\left.8.0 \mathrm{~Hz}, 1 \mathrm{H}, \mathrm{H}-1_{\mathrm{A}}\right), 5.58(\mathrm{~s}, 1 \mathrm{H}, \mathrm{PhCH}), 5.44\left(\mathrm{~d}, J=3.0 \mathrm{~Hz}, 1 \mathrm{H}, \mathrm{H}-1_{\mathrm{B}}\right)$, $5.16\left(\mathrm{t}, J=8.0 \mathrm{~Hz}, 1 \mathrm{H}, \mathrm{H}-2_{\mathrm{D}}\right), 4.84-4.68(\mathrm{~m}, 6 \mathrm{H}, 6 \mathrm{PhCH}), 4.67$ (br s, 1 $\left.\mathrm{H}, \mathrm{H}-1_{\mathrm{C}}\right), 4.66-4.33$ (m, $\left.7 \mathrm{H}, \mathrm{H}-2_{\mathrm{A}}, 6 \mathrm{PhCH}\right), 4.01$ (d, J = 8.0 Hz, $1 \mathrm{H}, \mathrm{H}-$ $\left.1_{\mathrm{D}}\right), 3.96-3.90\left(\mathrm{~m}, 2 \mathrm{H}, \mathrm{H}-3_{\mathrm{C}}, \mathrm{H}-6_{\mathrm{aA}}\right), 3.88-3.76\left(\mathrm{~m}, 3 \mathrm{H}, \mathrm{H}-3_{\mathrm{B}}, \mathrm{H}-3_{\mathrm{D}}, \mathrm{H}-\right.$ $\left.4_{\mathrm{C}}\right), 3.72-3.66\left(\mathrm{~m}, 2 \mathrm{H}, \mathrm{H}-4_{\mathrm{D}}, \mathrm{H}-5_{\mathrm{B}}\right), 3.64\left(\mathrm{~s}, 3 \mathrm{H}, \mathrm{OCH}_{3}\right), 3.62-3.50(\mathrm{~m}, 3$ 
$\left.\mathrm{H}, \mathrm{H}-2_{\mathrm{B}}, \mathrm{H}-3_{\mathrm{A}}, \mathrm{H}-4_{\mathrm{B}}\right), 3.49-3.32\left(\mathrm{~m}, 5 \mathrm{H}, \mathrm{H}-4_{\mathrm{A}}, \mathrm{H}-5_{\mathrm{C}}, \mathrm{H}-6_{\mathrm{bA}}, \mathrm{H}-6_{\mathrm{abB}}\right)$, 3.30-3.25 ( $\left.\mathrm{m}, 2 \mathrm{H}, \mathrm{H}-5_{\mathrm{A}}, \mathrm{H}-5_{\mathrm{D}}\right), 3.20-3.11\left(\mathrm{~m}, 2 \mathrm{H}, \mathrm{H}-2_{\mathrm{C}}, \mathrm{H}-6_{\mathrm{ac}}\right), 2.52-$ $2.48\left(\mathrm{~m}, 1 \mathrm{H}, \mathrm{H}-6_{\mathrm{bc}}\right), 1.74\left(\mathrm{~s}, 3 \mathrm{H}, \mathrm{COCH}_{3}\right), 1.17\left(\mathrm{~s}, 3 \mathrm{H}, \mathrm{CCH}_{3}\right)$.

${ }^{13} \mathrm{C}$ NMR $\left(125 \mathrm{MHz}, \mathrm{CDCl}_{3}\right): \delta=168.9\left(\mathrm{COCH}_{3}\right), 155.6-114.5(\mathrm{Ar}-\mathrm{C})$, 101.6 (PhCH), $100.2\left(\mathrm{C}-1_{\mathrm{D}}\right), 99.4\left(\mathrm{C}-1_{\mathrm{C}}\right), 99.0\left(\mathrm{C}-1_{\mathrm{B}}\right), 98.2\left(\mathrm{C}-1_{\mathrm{A}}\right), 82.4$ $\left(\mathrm{C}-4_{\mathrm{A}}\right), 81.8\left(\mathrm{C}-3_{\mathrm{B}}\right), 80.1\left(\mathrm{C}-4_{\mathrm{D}}\right), 79.6\left(\mathrm{C}-2_{\mathrm{C}}\right), 77.5\left(\mathrm{CH}_{2} \mathrm{Ph}\right), 75.1\left(\mathrm{C}-3_{\mathrm{A}}\right)$, $74.9\left(\mathrm{CH}_{2} \mathrm{Ph}\right), 74.6\left(\mathrm{C}-3_{\mathrm{C}}\right), 74.5\left(\mathrm{CH}_{2} \mathrm{Ph}\right), 74.4\left(\mathrm{C}-4_{\mathrm{B}}\right), 74.0\left(\mathrm{C}-4_{\mathrm{C}}\right), 73.9$ $\left(\mathrm{CH}_{2} \mathrm{Ph}\right), 73.8\left(\mathrm{CH}_{2} \mathrm{Ph}\right), 72.2\left(\mathrm{C}-3_{\mathrm{D}}\right), 72.1\left(\mathrm{C}-2_{\mathrm{D}}\right), 72.0\left(2 \mathrm{C}, 2 \mathrm{CH}_{2} \mathrm{Ph}\right)$, $69.8\left(\mathrm{C}-5_{\mathrm{C}}\right), 69.7\left(\mathrm{C}-5_{\mathrm{B}}\right), 69.6\left(\mathrm{C}-5_{\mathrm{D}}\right), 68.6\left(\mathrm{C}-6_{\mathrm{A}}\right), 67.0\left(\mathrm{C}-6_{\mathrm{C}}\right), 66.8(\mathrm{C}-$ $\left.6_{\mathrm{B}}\right), 66.1\left(\mathrm{C}-5_{\mathrm{A}}\right), 58.9\left(\mathrm{C}-2_{\mathrm{B}}\right), 55.5\left(\mathrm{OCH}_{3}\right), 55.2\left(\mathrm{C}-2_{\mathrm{A}}\right), 20.8\left(\mathrm{COCH}_{3}\right)$, $17.4\left(\mathrm{CCH}_{3}\right)$.

HRMS (ESI): $m / z[M+H]^{+}$calcd for $\mathrm{C}_{90} \mathrm{H}_{91} \mathrm{~N}_{7} \mathrm{O}_{21}$ (1605.6268): 1606.6346; found: 1606.6333 .

p-Methoxyphenyl (3-Azido-4-0-benzyl-3-deoxy- $\beta$-D-fucopyranosyl)-( $1 \rightarrow 6)$-(2,3,4-tri-0-benzyl- $\alpha$-D-glucopyranosyl)-( $1 \rightarrow 4)-(2$-azido-3,6-di-O-benzyl-2-deoxy- $\alpha$-D-galactopyranosyl)-(1 $\rightarrow 3)-4,6-0$ benzylidene-2-deoxy-2- $N$-phthalimido- $\beta$-D-glucopyranoside (16)

A solution of 15 (600 mg, $0.37 \mathrm{mmol}$ ) in $0.01 \mathrm{M} \mathrm{CH}_{3} \mathrm{ONa}$ in $\mathrm{CH}_{3} \mathrm{OH}(15$ $\mathrm{mL}$ ) was stirred at r.t. for $1 \mathrm{~h}$, neutralized with Amberlite IR-120 $\left(\mathrm{H}^{+}\right)$ resin, filtered, and concentrated. The crude product was purified by column chromatography (silica gel, hexane/EtOAc 2:1) to give pure 16 $(486 \mathrm{~g}, 84 \%)$ as a colorless oil.

$[\alpha]_{D}-16.0\left(c 1.0, \mathrm{CHCl}_{3}\right)$.

${ }^{1} \mathrm{H}$ NMR $\left(500 \mathrm{MHz}, \mathrm{CDCl}_{3}\right): \delta=7.66-6.61(\mathrm{~m}, 43 \mathrm{H}, \mathrm{Ar}-\mathrm{H}), 5.67(\mathrm{~d}, J=$ $\left.8.5 \mathrm{~Hz}, 1 \mathrm{H}, \mathrm{H}-1_{\mathrm{A}}\right), 5.58(\mathrm{~s}, 1 \mathrm{H}, \mathrm{PhCH}), 5.36\left(\mathrm{~d}, J=3.0 \mathrm{~Hz}, 1 \mathrm{H}, \mathrm{H}-1_{\mathrm{B}}\right)$, $4.89\left(\mathrm{t}, J=9.0 \mathrm{~Hz}, 1 \mathrm{H}, \mathrm{H}-2_{\mathrm{A}}\right), 4.75-4.65\left(\mathrm{~m}, 4 \mathrm{H}, 4 \mathrm{CH}_{2} \mathrm{Ph}\right), 4.61-4.56$ (m, $\left.4 \mathrm{H}, \mathrm{H}-1_{\mathrm{C}}, 3 \mathrm{CH}_{2} \mathrm{Ph}\right), 4.51-4.45\left(\mathrm{~m}, 2 \mathrm{H}, \mathrm{H}-3_{\mathrm{A}}, \mathrm{CH}_{2} \mathrm{Ph}\right), 4.40-4.34$ (m, $\left.3 \mathrm{H}, \mathrm{H}-6_{\mathrm{aA}}, 2 \mathrm{CH}_{2} \mathrm{Ph}\right), 3.98-3.92\left(\mathrm{~m}, 3 \mathrm{H}, \mathrm{H}-1_{\mathrm{D}}, \mathrm{H}-4_{\mathrm{A}}, \mathrm{H}-3_{\mathrm{C}}\right.$ ), 3.80$3.77\left(\mathrm{~m}, 3 \mathrm{H}, \mathrm{H}-6_{\mathrm{bA}} 2 \mathrm{CH}_{2} \mathrm{Ph}\right), 3.70-3.67\left(\mathrm{~m}, 2 \mathrm{H}, \mathrm{H}-3_{\mathrm{B}}, \mathrm{H}-5_{\mathrm{c}}\right), 3.63(\mathrm{~s}, 3$ $\left.\mathrm{H}, \mathrm{OCH}_{3}\right), 3.57-3.52\left(\mathrm{~m}, 3 \mathrm{H}, \mathrm{H}-4_{\mathrm{D}}, \mathrm{H}-2_{\mathrm{B}}, \mathrm{H}-6_{\mathrm{aC}}\right), 3.45-3.40(\mathrm{~m}, 3 \mathrm{H}, \mathrm{H}-$ $\left.2_{\mathrm{D}}, \mathrm{H}-3_{\mathrm{D}}, \mathrm{H}-5_{\mathrm{A}}\right), 3.34-3.20\left(\mathrm{~m}, 5 \mathrm{H}, \mathrm{H}-2_{\mathrm{C}}, \mathrm{H}-4_{\mathrm{C}}, \mathrm{H}-5_{\mathrm{B}}, \mathrm{H}-4_{\mathrm{B}}, \mathrm{H}-6_{\mathrm{aB}}\right)$, $3.12-3.10\left(\mathrm{~m}, 2 \mathrm{H}, \mathrm{H}-5_{\mathrm{D}}, \mathrm{H}-6_{\mathrm{bB}}\right), 2.49-2.45\left(\mathrm{~m}, 1 \mathrm{H}, \mathrm{H}-6_{\mathrm{bC}}\right), 1.21$ (d, $J=$ $\left.6.5 \mathrm{~Hz}, 3 \mathrm{H}, \mathrm{CCH}_{3}\right)$.

${ }^{13} \mathrm{C}$ NMR (125 MHz, $\left.\mathrm{CDCl}_{3}\right): \delta=155.7-114.5(\mathrm{Ar}-\mathrm{C}), 101.7(\mathrm{PhCH})$, $100.4\left(\mathrm{C}-1_{\mathrm{D}}\right), 99.4\left(\mathrm{C}-1_{\mathrm{C}}\right), 98.9\left(\mathrm{C}-1_{\mathrm{B}}\right), 98.1\left(\mathrm{C}-1_{\mathrm{A}}\right), 83.1\left(\mathrm{C}-4_{\mathrm{A}}\right), 82.4(\mathrm{C}-$ $\left.3_{\mathrm{B}}\right), 81.8\left(\mathrm{C}-4_{\mathrm{D}}\right), 79.8\left(\mathrm{C}-2_{\mathrm{C}}\right), 77.7\left(\mathrm{C}-4_{\mathrm{B}}\right), 75.1\left(\mathrm{CH}_{2} \mathrm{Ph}\right), 74.9\left(\mathrm{C}-3_{\mathrm{A}}\right), 74.6$ $\left(\mathrm{C}-3_{\mathrm{C}}\right), 74.5\left(\mathrm{CH}_{2} \mathrm{Ph}\right), 74.4\left(\mathrm{C}-4_{\mathrm{B}}\right), 74.0\left(\mathrm{CH}_{2} \mathrm{Ph}\right), 73.9\left(\mathrm{CH}_{2} \mathrm{Ph}\right), 73.8(\mathrm{C}-$ $\left.4_{C}\right), 72.2\left(\mathrm{C}-3_{\mathrm{D}}\right), 72.1\left(\mathrm{C}-2_{\mathrm{D}}\right), 72.0\left(2 \mathrm{C}, 2 \mathrm{CH}_{2} \mathrm{Ph}\right), 71.5\left(\mathrm{C}-5_{\mathrm{C}}\right), 69.9(\mathrm{C}-$ $\left.5_{B}\right), 69.7\left(C-5_{D}\right), 68.6\left(C-6_{A}\right), 67.0\left(C-6_{C}\right), 66.8\left(C-6_{B}\right), 66.1\left(C-5_{A}\right), 59.0$ $\left(\mathrm{C}-2_{\mathrm{B}}\right), 55.5\left(\mathrm{OCH}_{3}\right), 55.2\left(\mathrm{C}-2_{\mathrm{A}}\right), 17.6\left(\mathrm{CCH}_{3}\right)$.

HRMS (ESI): $m / z[\mathrm{M}+\mathrm{H}]^{+}$calcd for $\mathrm{C}_{88} \mathrm{H}_{89} \mathrm{~N}_{7} \mathrm{O}_{20}$ (1563.6162): 1564.6240; found: 1564.6228 .

\section{p-Methoxyphenyl (2,3,4-Tri-0-acetyl-6-0-benzyl- $\beta$-D-glucopyra- nosyl)-( $1 \rightarrow 2)$-(3-azido-4-0-benzyl-3-deoxy- $\beta$-D-fucopyranosyl)- $(1 \rightarrow 6)-(2,3,4-$ tri-O-benzyl- $\alpha$-D-glucopyranosyl)-( $1 \rightarrow 4)$-(2-azido- 3,6-di-0-benzyl-2-deoxy- $\alpha$-D-galactopyranosyl)-( $1 \rightarrow 3)-4,6-0$-ben- zylidene-2-deoxy-2- $N$-phthalimido- $\beta$-D-glucopyranoside (17)}

To a solution of $\mathbf{1 6}(200 \mathrm{mg}, 0.13 \mathrm{mmol})$ and $\mathbf{6}(130 \mathrm{mg}, 0.26 \mathrm{mmol})$ in anhyd $\mathrm{CH}_{2} \mathrm{Cl}_{2}(5 \mathrm{~mL})$ was added MS $4 \AA$ ( $\left.0.3 \mathrm{~g}\right)$ and the mixture was cooled to $-10{ }^{\circ} \mathrm{C}$ under argon. To the cooled mixture were added NIS (65 mg, $0.28 \mathrm{mmol}$ ) and $\mathrm{HClO}_{4}-\mathrm{SiO}_{2}(5 \mathrm{mg})$ and it was stirred at $-20{ }^{\circ} \mathrm{C}$ for $3 \mathrm{~h}$. The mixture was filtered through a Celite bed and washed with $\mathrm{CH}_{2} \mathrm{Cl}_{2}(20 \mathrm{~mL})$. The combined organic layers were successively washed with $5 \% \mathrm{Na}_{2} \mathrm{~S}_{2} \mathrm{O}_{3}(10 \mathrm{~mL})$, sat. $\mathrm{NaHCO}_{3}(10 \mathrm{~mL})$, and $\mathrm{H}_{2} \mathrm{O}(10$ $\mathrm{mL})$, dried $\left(\mathrm{Na}_{2} \mathrm{SO}_{4}\right)$, and concentrated. The crude product was purified by column chromatography (silica gel, hexane/EtOAc 2:1) to give pure 17 (160 mg, 64\%) as a colorless oil.

$[\alpha]_{D}-26.0\left(c 1.0, \mathrm{CHCl}_{3}\right)$.
${ }^{1} \mathrm{H}$ NMR $\left(500 \mathrm{MHz}, \mathrm{CDCl}_{3}\right): \delta=7.27-6.61(\mathrm{~m}, 48 \mathrm{H}, \mathrm{Ar}-\mathrm{H}), 5.52(\mathrm{~d}, J=$ $\left.8.0 \mathrm{~Hz}, 1 \mathrm{H}, \mathrm{H}-1_{\mathrm{A}}\right), 5.08\left(\mathrm{t}, J=9.0 \mathrm{~Hz}, 1 \mathrm{H}, \mathrm{H}-3_{\mathrm{A}}\right), 4.95(\mathrm{~d}, J=3.0 \mathrm{~Hz}, 1 \mathrm{H}$, $\left.\mathrm{H}-1_{\mathrm{B}}\right), 4.92-4.81\left(\mathrm{~m}, 3 \mathrm{H}, \mathrm{PhCH}, \mathrm{H}-3_{\mathrm{E}}, \mathrm{CHPh}\right), 4.82-4.65(\mathrm{~m}, 6 \mathrm{H}, 6$ $\mathrm{CHPh}), 4.65$ (d, J = 3.0 Hz, $\left.1 \mathrm{H}, \mathrm{H}-1_{\mathrm{C}}\right), 4.64-4.57$ (m, $\left.3 \mathrm{H}, 3 \mathrm{CHPh}\right), 4.53-$ $4.42\left(\mathrm{~m}, 5 \mathrm{H}, 4 \mathrm{CH}_{2} \mathrm{Ph}, \mathrm{H}-2_{\mathrm{E}}\right), 4.40-4.30\left(\mathrm{~m}, 2 \mathrm{H}, \mathrm{H}-2_{\mathrm{A}}, \mathrm{H}-4_{\mathrm{E}}\right), 4.00-3.98$ $\left(2 \mathrm{~d}, J=8.0 \mathrm{~Hz}, 2 \mathrm{H}, \mathrm{H}-1_{\mathrm{D}}, \mathrm{H}-1_{\mathrm{E}}\right), 3.97-3.93\left(\mathrm{~m}, 2 \mathrm{H}, \mathrm{H}-3_{\mathrm{C}}, \mathrm{H}-4_{\mathrm{A}}\right), 3.90-$ $3.82\left(\mathrm{~m}, 2 \mathrm{H}, \mathrm{H}-3_{\mathrm{B}}, \mathrm{H}-5_{\mathrm{C}}\right), 3.83-3.78$ ( $\left.\mathrm{m}, 2 \mathrm{H}, \mathrm{H}-6_{\mathrm{aA}}, \mathrm{H}-3_{\mathrm{D}}\right), 3.77-3.70$ (m, $3 \mathrm{H}, \mathrm{H}-2_{\mathrm{B}}, \mathrm{H}-5_{\mathrm{A}}, \mathrm{H}-5_{\mathrm{E}}$ ), 3.65 (dd, $\left.J=10.0,3.0 \mathrm{~Hz}, 1 \mathrm{H}, \mathrm{H}-6_{\mathrm{bA}}\right), 3.63$ (s, $\left.3 \mathrm{H}, \mathrm{OCH}_{3}\right), 3.52-3.33\left(\mathrm{~m}, 8 \mathrm{H}, \mathrm{H}-2_{\mathrm{C}}, \mathrm{H}-4_{\mathrm{B}}, \mathrm{H}-4_{\mathrm{D}}, \mathrm{H}-5_{\mathrm{B}}, \mathrm{H}-6_{\mathrm{abc}}, \mathrm{H}-\right.$ $\left.6_{\mathrm{abE}}\right), 3.27\left(\mathrm{t}, J=8.5 \mathrm{~Hz}, 1 \mathrm{H}, \mathrm{H}-2_{\mathrm{D}}\right), 3.21\left(\mathrm{t}, J=9.0 \mathrm{~Hz}, 1 \mathrm{H}, \mathrm{H}-4_{\mathrm{C}}\right), 3.19-$ $3.09\left(\mathrm{~m}, 2 \mathrm{H}, \mathrm{H}-5_{\mathrm{D}}, \mathrm{H}-6_{\mathrm{aB}}\right), 2.52-2.49\left(\mathrm{~m}, 1 \mathrm{H}, \mathrm{H}-6_{\mathrm{bB}}\right), 2.05$ (s, $3 \mathrm{H}, \mathrm{CO}-$ $\left.\mathrm{CH}_{3}\right), 2.0\left(\mathrm{~s}, 3 \mathrm{H}, \mathrm{COCH}_{3}\right), 1.97\left(\mathrm{~s}, 3 \mathrm{H}, \mathrm{COCH}_{3}\right), 1.07$ (d, $\mathrm{J}=6.5 \mathrm{~Hz}, 3 \mathrm{H}$, $\left.\mathrm{CCH}_{3}\right)$.

${ }^{13} \mathrm{C}$ NMR $\left(125 \mathrm{MHz}, \mathrm{CDCl}_{3}\right): \delta=170.2\left(\mathrm{COCH}_{3}\right), 169.4\left(\mathrm{COCH}_{3}\right), 168.9$ $\left(\mathrm{COCH}_{3}\right), 155.5-114.2(\mathrm{Ar}-\mathrm{C}), 101.8(\mathrm{PhCH}), 100.5\left(\mathrm{C}-1_{\mathrm{E}}\right), 100.4\left(\mathrm{C}-1_{\mathrm{D}}\right)$, $99.4\left(\mathrm{C}-1_{\mathrm{C}}\right), 98.9\left(\mathrm{C}-1_{\mathrm{B}}\right), 98.1\left(\mathrm{C}-1_{\mathrm{A}}\right), 83.1\left(\mathrm{C}-4_{\mathrm{A}}\right), 83.0\left(\mathrm{C}-2_{\mathrm{E}}\right), 82.4(\mathrm{C}-$ $\left.3_{\mathrm{B}}\right), 81.8\left(\mathrm{C}-4_{\mathrm{D}}\right), 80.8\left(\mathrm{C}-4_{\mathrm{E}}\right), 79.8\left(\mathrm{C}-2_{\mathrm{C}}\right), 77.7\left(\mathrm{CH}_{2} \mathrm{Ph}\right), 75.1\left(\mathrm{CH}_{2} \mathrm{Ph}\right)$, $74.9\left(\mathrm{C}-3_{\mathrm{A}}\right), 74.6\left(\mathrm{C}-3_{\mathrm{C}}\right), 74.5\left(\mathrm{CH}_{2} \mathrm{Ph}\right), 74.4\left(\mathrm{C}-4_{\mathrm{B}}\right), 74.0\left(\mathrm{CH}_{2} \mathrm{Ph}\right), 73.9$ $\left(\mathrm{CH}_{2} \mathrm{Ph}\right), 73.8\left(\mathrm{C}-4_{\mathrm{C}}\right), 73.3\left(\mathrm{CH}_{2} \mathrm{Ph}\right), 72.2\left(\mathrm{C}-3_{\mathrm{D}}\right), 72.1\left(\mathrm{C}-2_{\mathrm{D}}\right), 72.0$ $\left(\mathrm{CH}_{2} \mathrm{Ph}\right), 71.5\left(\mathrm{C}-5_{\mathrm{A}}\right), 70.9\left(\mathrm{C}-3_{\mathrm{E}}\right), 70.2\left(\mathrm{C}-5_{\mathrm{C}}\right), 69.9\left(\mathrm{C}-5_{\mathrm{B}}\right), 69.7\left(\mathrm{C}-5_{\mathrm{D}}\right)$, $69.6\left(\mathrm{H}-5_{\mathrm{E}}\right), 66.6\left(\mathrm{C}-6_{\mathrm{E}}\right), 66.9\left(\mathrm{C}-6_{\mathrm{C}}\right), 66.8\left(\mathrm{C}-6_{\mathrm{B}}\right), 66.1\left(\mathrm{C}-6_{\mathrm{A}}\right), 59.0(\mathrm{C}-$ $\left.2_{\mathrm{B}}\right), 55.5\left(\mathrm{OCH}_{3}\right), 55.2\left(\mathrm{C}-2_{\mathrm{A}}\right), 20.9\left(\mathrm{COCH}_{3}\right), 20.7\left(2 \mathrm{C}, 2 \mathrm{COCH}_{3}\right), 17.6$ $\left(\mathrm{CCH}_{3}\right)$.

HRMS (ESI): $m / z[\mathrm{M}+\mathrm{H}]^{+}$calcd for $\mathrm{C}_{107} \mathrm{H}_{111} \mathrm{~N}_{7} \mathrm{O}_{28}$ (1941.7477): 1942.7555; found: 1942.7540 .

p-Methoxyphenyl ( $\beta$-D-Glucopyranosyl)-(1 $\rightarrow 2)$-(3-acetamido-3deoxy- $\beta$-D-fucopyranosyl)-( $1 \rightarrow 6)$-( $\alpha$-D-glucopyranosyl)-( $1 \rightarrow 4)-(2$ acetamido-2-deoxy- $\alpha$-D-galactopyranosyl)-( $(1 \rightarrow 3)$-2-acetamido-2deoxy- $\beta$-D-glucopyranoside (1)

To a solution of $\mathbf{1 7}(100 \mathrm{mg}, 0.05 \mathrm{mmol})$ in EtOH $(10 \mathrm{~mL})$ was added $\mathrm{NH}_{2} \mathrm{NH}_{2} \cdot \mathrm{H}_{2} \mathrm{O}(0.7 \mathrm{~mL})$ and the mixture was stirred $80^{\circ} \mathrm{C}$ for $12 \mathrm{~h}$. The solvents were removed under reduced pressure and a solution of the crude product in $\mathrm{Ac}_{2} \mathrm{O}(2 \mathrm{~mL})$ and pyridine $(2 \mathrm{~mL})$ was kept at r.t. for 4 h. To a solution of the acetylated product in pyridine $(2 \mathrm{~mL})$ was added $\mathrm{CH}_{3} \mathrm{COSH}(1.0 \mathrm{~mL})$ and the mixture was stirred at r.t. for $12 \mathrm{~h}$. The solvents were removed and co-evaporated with toluene $(3 \times 20 \mathrm{~mL})$ under reduced pressure and the crude product was passed through a short pad of silica gel. A solution of the $N$-acetylated product in $0.1 \mathrm{M}$ $\mathrm{CH}_{3} \mathrm{ONa}$ in $\mathrm{CH}_{3} \mathrm{OH}(10 \mathrm{~mL})$ was stirred at r.t. for $6 \mathrm{~h}$, neutralized with Amberlite IR-120 $\left(\mathrm{H}^{+}\right)$resin, filtered, and concentrated. To the solution of the de- $\mathrm{O}$-acetylated product in $\mathrm{CH}_{3} \mathrm{OH}(5 \mathrm{~mL})$ was added $20 \%$ $\mathrm{Pd}(\mathrm{OH})_{2}-\mathrm{C}(25 \mathrm{mg})$ and the mixture was stirred at r.t. under a positive pressure of $\mathrm{H}_{2}$ for $24 \mathrm{~h}$. The mixture was filtered through a Celite bed, washed with $\mathrm{CH}_{3} \mathrm{OH} / \mathrm{H}_{2} \mathrm{O}(20 \mathrm{~mL} ; 2: 1)$, and concentrated under reduced pressure. The deprotected product was passed through a Sephadex $\mathrm{LH}-20$ column $\left(\mathrm{CH}_{3} \mathrm{OH} / \mathrm{H}_{2} \mathrm{O} 3: 1\right)$ to give pure $\mathbf{1}(27 \mathrm{mg}, 52 \%)$ as a white powder.

$[\alpha]_{D}-16.0\left(\right.$ c $\left.0.5, \mathrm{H}_{2} \mathrm{O}\right)$.

${ }^{1} \mathrm{H}$ NMR (500 MHz, $\mathrm{D}_{2} \mathrm{O}$ ): $\delta$ = 7.20-6.91 (m, $4 \mathrm{H}, \mathrm{Ar}-\mathrm{H}$ ), 5.25 (br s, $1 \mathrm{H}$, $\mathrm{H}-1_{\mathrm{C}}$ ), 4.97 (br s, $1 \mathrm{H}, \mathrm{H}-1_{\mathrm{B}}$ ), 4.95 (d, $\left.J=9.5 \mathrm{~Hz}, 1 \mathrm{H}, \mathrm{H}-1_{\mathrm{A}}\right), 4.52$ (d, $J=$ $\left.9.0 \mathrm{~Hz}, 1 \mathrm{H}, \mathrm{H}-1_{\mathrm{D}}\right), 4.32$ (d, J = 9.0 Hz, $\left.1 \mathrm{H}, \mathrm{H}-1_{\mathrm{E}}\right), 4.13-3.96$ ( $\mathrm{m}, 3 \mathrm{H}, \mathrm{H}-$ $\left.2_{\mathrm{D}}, \mathrm{H}-3_{\mathrm{B}}, \mathrm{H}-4_{\mathrm{D}}\right), 3.95-3.86\left(\mathrm{~m}, 2 \mathrm{H}, \mathrm{H}-6_{\mathrm{aA}}, \mathrm{H}-6_{\mathrm{aC}}\right), 3.85-3.79(\mathrm{~m}, 4 \mathrm{H}, \mathrm{H}-$ $\left.5_{\mathrm{A}}, \mathrm{H}-5_{\mathrm{C}}, \mathrm{H}-3_{\mathrm{E}}, \mathrm{H}-2_{\mathrm{B}}\right), 3.71-3.65$ (m, $9 \mathrm{H}, \mathrm{H}-6_{\mathrm{abE}}, \mathrm{H}-6_{\mathrm{bC}}, \mathrm{H}-6_{\mathrm{bA}}, \mathrm{H}-2_{\mathrm{E}}, \mathrm{H}-$ $\left.4_{\mathrm{B}}, \mathrm{OCH}_{3}\right), 3.64-3.59$ ( $\left.\mathrm{m}, 5 \mathrm{H}, \mathrm{H}-2_{\mathrm{C}}, \mathrm{H}-3_{\mathrm{A}}, \mathrm{H}-3_{\mathrm{D}}, \mathrm{H}-4_{\mathrm{C}}, \mathrm{H}-6_{\mathrm{aB}}\right), 3.53-3.50$ ( $\left.\mathrm{m}, 2 \mathrm{H}, \mathrm{H}-5_{\mathrm{D}}, \mathrm{H}-6_{\mathrm{bB}}\right), 3.45-3.40\left(\mathrm{~m}, 3 \mathrm{H}, \mathrm{H}-2_{\mathrm{A}}, \mathrm{H}-3_{\mathrm{C}}, \mathrm{H}-4_{\mathrm{E}}\right), 3.35-3.21$ $\left(\mathrm{m}, 3 \mathrm{H}, \mathrm{H}-4_{\mathrm{A}}, \mathrm{H}-5_{\mathrm{B}}, \mathrm{H}-5_{\mathrm{E}}\right), 2.05\left(\mathrm{~s}, 3 \mathrm{H}, \mathrm{NHCOCH}_{3}\right), 1.97(2 \mathrm{~s}, 6 \mathrm{H}, 2$ $\left.\mathrm{NHCOCH}_{3}\right), 0.76\left(\mathrm{~d}, \mathrm{~J}=6.5 \mathrm{~Hz}, 3 \mathrm{H}, \mathrm{CCH}_{3}\right)$.

${ }^{13} \mathrm{C}$ NMR $\left(125 \mathrm{MHz}, \mathrm{D}_{2} \mathrm{O}\right): \delta=170.2\left(\mathrm{COCH}_{3}\right), 169.4\left(\mathrm{COCH}_{3}\right), 168.9$ $\left(\mathrm{COCH}_{3}\right), 154.7-115.4(\mathrm{Ar}-\mathrm{C}), 102.8\left(\mathrm{C}-1_{\mathrm{D}}\right), 102.6\left(\mathrm{C}-1_{\mathrm{E}}\right), 101.1\left(\mathrm{C}-1_{\mathrm{A}}\right)$, $101.0\left(\mathrm{C}-1_{\mathrm{B}}\right), 98.9\left(\mathrm{C}-1_{\mathrm{C}}\right), 79.0\left(\mathrm{C}-2_{\mathrm{E}}\right), 77.6\left(\mathrm{C}-4_{\mathrm{B}}\right), 76.1\left(\mathrm{C}-3_{\mathrm{E}}\right), 75.0(\mathrm{C}-$ 
$\left.5_{\mathrm{E}}\right), 74.6\left(\mathrm{C}-5_{\mathrm{A}}\right), 74.0\left(\mathrm{C}-2_{\mathrm{D}}\right), 73.5\left(\mathrm{C}-2_{\mathrm{C}}\right), 73.0\left(2 \mathrm{C}, \mathrm{C}-5_{\mathrm{C}}, \mathrm{C}-5_{\mathrm{D}}\right), 72.6(2$ C, C-3 $\left.{ }_{C}, C-5_{B}\right), 72.0\left(3 \mathrm{C}, C-3_{A}, C-4_{C}, C-4_{D}\right), 71.6\left(C-4_{E}\right), 71.1\left(C-4_{A}\right), 69.6$ $\left(\mathrm{C}-3_{\mathrm{B}}\right), 68.1\left(\mathrm{C}-6_{\mathrm{C}}\right), 67.5\left(\mathrm{C}-3_{\mathrm{D}}\right), 62.8\left(\mathrm{C}-6_{\mathrm{A}}\right), 60.9\left(\mathrm{C}-6_{\mathrm{E}}\right), 59.9\left(\mathrm{C}-6_{\mathrm{B}}\right)$, $56.1\left(\mathrm{OCH}_{3}\right), 55.5\left(\mathrm{C}-2_{\mathrm{A}}\right), 50.8\left(\mathrm{C}-2_{\mathrm{B}}\right), 22.5\left(\mathrm{NHCOCH}_{3}\right), 20.8(\mathrm{NHCO}-$ $\left.\mathrm{CH}_{3}\right), 20.4\left(\mathrm{NHCOCH}_{3}\right), 16.8\left(\mathrm{CCH}_{3}\right)$.

HRMS (ESI): $m / z[\mathrm{M}+\mathrm{H}]^{+}$calcd for $\mathrm{C}_{43} \mathrm{H}_{67} \mathrm{~N}_{3} \mathrm{O}_{26}$ (1041.4013): 1042.4091; found: 1042.4077 .

\section{Conflict of Interest}

The authors declare no conflict of interest.

\section{Funding Information}

A.G. and M.K. thank Council of Scientific and Industrial Research, New Delhi, India (CSIR) for providing senior research fellowships. This work was supported by Science and Engineering Research Board (SERB), New Delhi (Project No. CRG/2019/000352 dated 23.01.2020) (A.K.M.).

\section{Supporting Information}

Supporting information for this article is available online at https://doi.org/10.1055/s-0037-1610777. Copies of 1D and 2D NMR spectra of compounds $\mathbf{1}$ and 8-17 are provided.

\section{References}

(1) (a) Mandeville, K. L.; Krabshuis, J.; Ladep, N. G.; Mulder, C. J. J.; Quigley, E. M. M.; Khan, S. A. World J. Gastroenterol. 2009, 15, 2839. (b) Milivojevic, V.; Milosavljevic, T. Curr. Treat. Options Gastroenterol. 2020, 18, 148. (c) Dumic, I.; Nordin, T.; Jecmenica, M.; Lalosevic, M. S.; Milosavljevic, T.; Milovanovic, T. Can. J. Gastroenterol. Hepatol. 2019, 2019, 6757524, DOI: $10.1155 / 2019 / 6757524$.

(2) (a) Fletcher, S. M.; Mclaws, M.-L.; Ellis, J. T. J. Public Health Res. 2013, 2, 42. (b) Williams, J.; Roberts, S.; Ali, F.; Cheung, W.; Cohen, D.; Demery, G.; Edwards, A.; Greer, M.; Hellier, M.; Hutchings, H.; Ip, B.; Longo, M.; Russell, I.; Snooks, H.; Williams, J. Gut 2007, 56, 01 : 1. (c) Guerrant, R. L.; Hughes, J. M.; Lima, N. L.; Crane, J. Rev. Infect. Dis. 1990, 12, S41.

(3) (a) Oloruntoba, E. O.; Folarin, T. B.; Idowu-Ayede, A. Afr. Health Sci. 2014, 14, 1001. (b) Huttly, S. R.; Morris, S. S.; Pisani, V. Bull. W. H. O. 1997, 75, 163. (c) Florez, I. D.; Niño-Serna, L. F.; BeltráArroyave, C. P. Curr. Infect. Dis. Rep. 2020, 22, 4 DOI: 10.1007/s11908-020-0713-6.

(4) (a) Casburnn-Jones, A. C.; Farthing, M. J. G. Gut 2004, 53, 296. (b) Lima, A. A.; Guerrant, R. L. Epidemiol. Rev. 1992, 14, 222. (c) Niyogi, S. K.; Saha, M. R.; De, S. P. Indian J. Public Health 1994, 38, 29. (d) Shankar, P.; Mishra, J.; Bharti, V.; Parashar, D.; Singh, S. J. Lab. Physicians 2019, 11, 275.

(5) (a) Beatty, M. E.; Adcock, P. M.; Smith, S. W.; Quinlan, K.; Kamimoto, L. A.; Rowe, S. Y.; Scott, K.; Conover, C.; Varchmin, T.; Bopp, C. A.; Greene, K. D.; Bibb, B.; Slutsker, L.; Mintz, E. D. Clin. Infect. Dis. 2006, 42, 329. (b) Gomes, T. A. T.; Elias, W. P.; Scaletsky, I. C. A.; Guth, B. E. C.; Rodrigues, J. F.; Piazza, R. M. F.; Ferreira, L. C. S.; Martinez, M. B. Braz. J. Microbiol. 2016, 47, 3.

(6) Baker, S.; The, H. C. Curr. Opin. Infect. Dis. 2018, 31, 449.

(7) Davies, H. G.; Bowman, C.; Luby, S. P. J. Infect. 2017, 74, 01 : S66.
(8) Hamilton, A. L.; Kamm, M. A.; Ng, S. C.; Morrison, M. Clin. Microbiol. Rev. 2018, 31, e00085 DOI: 10.1128/CMR.00085-17.

(9) (a) Aljoudi, A. S.; Al-Mazam, A.; Choudhry, A. J. J. Family Community Med. 2010, 17, 29. (b) Lu, X.; Zeng, M.; Xu, J.; Zhou, H.; Gu, B.; Li, Z.; Jin, H.; Wang, X.; Zhang, W.; Hu, Y.; Xiao, W.; Zhu, B.; Xu, X.; Kan, B. EbioMedicine 2019, 42, 133.

(10) (a) Crum-Cianflone, N. F. Curr. Gastroenterol. Rep. 2008, 10, 424. (b) Zha, L.; Garrett, S.; Sun, J. Diseases 2019, 7, 28 DOI: 10.3390/diseases7010028.

(11) (a) Stoycheva, M. V.; Murdjeva, M. A. Folia Med. (Sofia, Bulg.) 2006, 48, 5. (b) Ray, K. A.; Warnick, L. D.; Mitchell, R. M.; Kaneene, J. B.; Ruegg, P. L.; Wells, S. J.; Fossler, C. P.; Halberd, L. W.; May, K. J. Dairy Sci. 2006, 89, 2038. (c) Mu, H.; Bai, H.; Sun, F.; Liu, Y.; Lu, C.; Qiu, Y.; Chen, P.; Yang, Y.; Kong, L.; Duan, J. Nat. Commun. 2019, 10, 4039. (d) Hirose, K.; Tamura, K.; Sagara, H.; Watanabe, H. Antimicrob. Agents Chemother. 2001, 45, 956.

(12) (a) Jajere, S. M. Vet. World 2019, 12, 504. (b) Eng, S.-K.; Pusparajah, P.; Ab Mutalib, N.-S.; Ser, H.-L.; Chan, K.-G.; Lee, L.H. Front. Life Sci. 2015, 8, 284.

(13) (a) Fair, R. J.; Tor, Y. Perspect. Med. Chem. 2014, 6, 25. (b) Appelbaum, P. C. J. Antimicrob. Chemother. 2012, 67, 2062. (c) Sipahi, O. R. Expert Rev. Anti-Infect. Ther. 2008, 6, 523.

(14) (a) Moxon, E. R.; Kroll, J. S. Curr. Top. Microbiol. Immunol. 1990, 150, 65. (b) Taylor, C. M.; Roberts, I. S. Contrib. Microbiol. 2005 , $12,55$.

(15) Liu, B.; Perepelov, A. V.; Svensson, M. V.; Shevelev, S. D.; Guo, D.; Senchenkova, S. N.; Shashkov, A. S.; Weintraub, A.; Feng, L.; Widmalm, G.; Knirel, Y. A.; Wang, L. Glycobiology 2010, 20, 679.

(16) Gilchrist, S. A. N.; Nanni, A.; Levine, O. Am. J. Public Health 2012, 102, 596.

(17) (a) Thindwa, D.; Quesada, M. G.; Liu, Y.; Bennett, J.; Cohen, C.; Knoll, M. D.; von Gottberg, A.; Hayford, K.; Flasche, S. Vaccine 2020, 38, 5398. (b) Nichol, K. L. Vaccine 1999, 17, S91.

(18) (a) Pace, D.; Pollard, A. J. Arch. Dis. Child. 2007, 92, 909. (b) Poland, G. A. Clin. Infect. Dis. 2010, 50, S45.

(19) (a) Gucchait, A.; Shit, P.; Misra, A. K. Tetrahedron 2020, 76, 131412. (b) Dhara, D.; Baliban, S. M.; Huo, C. X.; Rashidijahanabad, Z.; Sears, K. T.; Nick, S. T.; Misra, A. K.; Tennant, S. M.; Huang, X. Chem. Eur. J. 2020, 26, 15953. (c) Huo, C.-X.; Dhara, D.; Baliban, S. M.; Nick, S. T.; Tan, Z.; Simon, S.; Misra, A. K.; Huang, X. Chem. Commun. 2019, 55, 4519. (d) Bhaumik, I.; Misra, A. K. ChemistrySelect 2017, 2, 3065. (e) Bhaumik, I.; Misra, A. K. ChemistrySelect 2017, 2, 937. (f) Dhara, D.; Misra, A. K. ChemistryOpen 2015, 4, 768. (g) Dhara, D.; Mandal, P. K.; Misra, A. K. Tetrahedron: Asymmetry 2014, 25 , 263. (h) Ghosh, T.; Santra, A.; Misra, A. K. Tetrahedron: Asymmetry 2013, 24, 606. (i) Sau, A.; Panchadhayee, R.; Ghosh, D.; Misra, A. K. Carbohydr. Res. 2012, 352, 18.

(20) Nicolaou, K. C.; Bockovich, N. J.; Carcanague, D. R.; Hummel, C. W.; Even, L. F. J. Am. Chem. Soc. 1992, 114, 8701.

(21) Kalikanda, J.; Li, Z. J. Org. Chem. 2011, 76, 5207.

(22) Hsu, Y.; Lu, X.-A.; Zulueta, M. L.; Tsai, C.-M.; Lin, K.-I.; Hung, S.C.; Wong, C.-H. J. Am. Chem. Soc. 2012, 134, 4549.

(23) Huang, T.-Y.; Zulueta, M. M. L.; Hung, S.-C. Org. Biomol. Chem. 2014, $12,376$.

(24) (a) Mukherjee, C.; Misra, A. K. Synthesis 2007, 683. (b) Manna, T.; Gucchait, A.; Misra, A. K. Beilstein J. Org. Chem. 2020, 16, 106. (c) Shit, P.; Misra, A. K. Glycoconjugate J. 2020, 37, 647. (d) Kundu, M.; Gucchait, A.; Misra, A. K. Tetrahedron 2020, 76, 130952. (e) Manna, T.; Misra, A. K. Carbohydr. Res. 2021, 502, 108294. (f) Kundu, M.; Misra, A. K. Carbohydr. Res. 2019, 486, 107830. (g) Shit, P.; Gucchait, A.; Misra, A. K. Tetrahedron 2019, 75, 130697. 
Synthesis

A. Gucchait et al.

(25) Chakraborti, A. K.; Gulhane, R. Chem. Commun. 2003, 1896.

(26) (a) Khatik, G. L.; Sharma, G.; Kumar, R.; Chakraborti, A. K. Tetrahedron 2007, 63, 1200. (b) Kumar, D.; Kommi, D. N.; Chebolu, R.; Garg, S. K.; Kumar, R.; Chakraborti, A. K. RSC Adv. 2013, 3, 91. (c) Kumar, D.; Sonawane, M.; Pujala, B.; Jain, V. K.; Bhagat, S.; Chakraborti, A. K. Green Chem. 2013, 15, 2872. (d) Rudrawar, S.; Besra, R. C.; Chakraborti, A. K. Synthesis 2006, 2767. (e) Kumar, R.; Kumar, D.; Chakraborti, A. K. Synthesis 2007, 299. (f) Chakraborti, A. K.; Sunay, V.; Chankeshwara, S. V. Org. Biomol. Chem. 2006, 4, 2769. (g) Agarwal, A.; Rani, S.; Vankar, Y. D. J. Org. Chem. 2004, 69, 6137. (h) Misra, A. K.; Tiwari, P.; Madhusudan, S. K. Carbohydr. Res. 2005, 340, 325. (i) Misra, A. K.; Tiwari, P.; Agnihotri, G. Synthesis 2005, 260. (j) Khan, A. T.; Choudhury, L. H.; Ghosh, S. J. Mol. Catal. A: Chem. 2006, 255, 230. (k) Ansari, M. I.; Hussain, M. K.; Yadav, N.; Gupta, P. K.; Hajela, K. Tetrahedron Lett. 2012, 53, 2063.

(27) (a) Das, R.; Mukhopadhyay, B. ChemistryOpen 2016, 5, 401. (b) Lian, G.; Zhang, X.; Yu, B. Carbohydr. Res. 2015, 403, 13. (c) Codée, J. D. C.; Litjens, R. E. J. N.; van den Bos, L. J.; Overkleeft, H. S.; van der Marel, G. A. Chem. Soc. Rev. 2005, 34, 769.
(28) Adak, A.; Mukhopadhyay, B. Carbohydr. Res. 2019, 476, 1.

(29) Kiyoi, T.; Nakai, Y.; Kondo, H.; Ishida, H.; Kiso, M.; Hasegawa, A. Bioorg. Med. Chem. 1996, 4, 1167.

(30) Brimacombe, J. S. Methods Carbohydr. Chem. 1972, 6, 376.

(31) Wuts, P. G. M. In Handbook of Reagents for Organic Synthesis: Reagents for Glycoside, Nucleotide, and Peptide Synthesis; Crich, D., Ed.; Wiley: Chichester, 2005, 425.

(32) Dong, H.; Rahm, M.; Thota, N.; Deng, L.; Brinck, T.; Ramström, O. Org. Biomol. Chem. 2013, 11, 648.

(33) Augé, C.; David, S.; Veyrières, A. J. Chem. Soc., Chem. Commun. 1976, 375.

(34) Dhakal, B.; Bohé, L.; Crich, D. J. Org. Chem. 2017, 82, 9263.

(35) Lloyd, D.; Bylsma, M.; Bright, D. K.; Chen, X.; Bennett, C. S. J. Org. Chem. 2017, 82, 3926.

(36) Lee, H.-H.; Schwartz, D. A.; Harris, J. F.; Carver, J. P.; Krepinsky, J. J. Can. J. Chem. 1986, 64, 1912.

(37) Shangguan, N.; Katukojvala, S.; Greenberg, R.; Williams, L. J. J. Am. Chem. Soc. 2003, 125, 7754.

(38) Pearlman, W. M. Tetrahedron Lett. 1967, 8, 1663. 